4

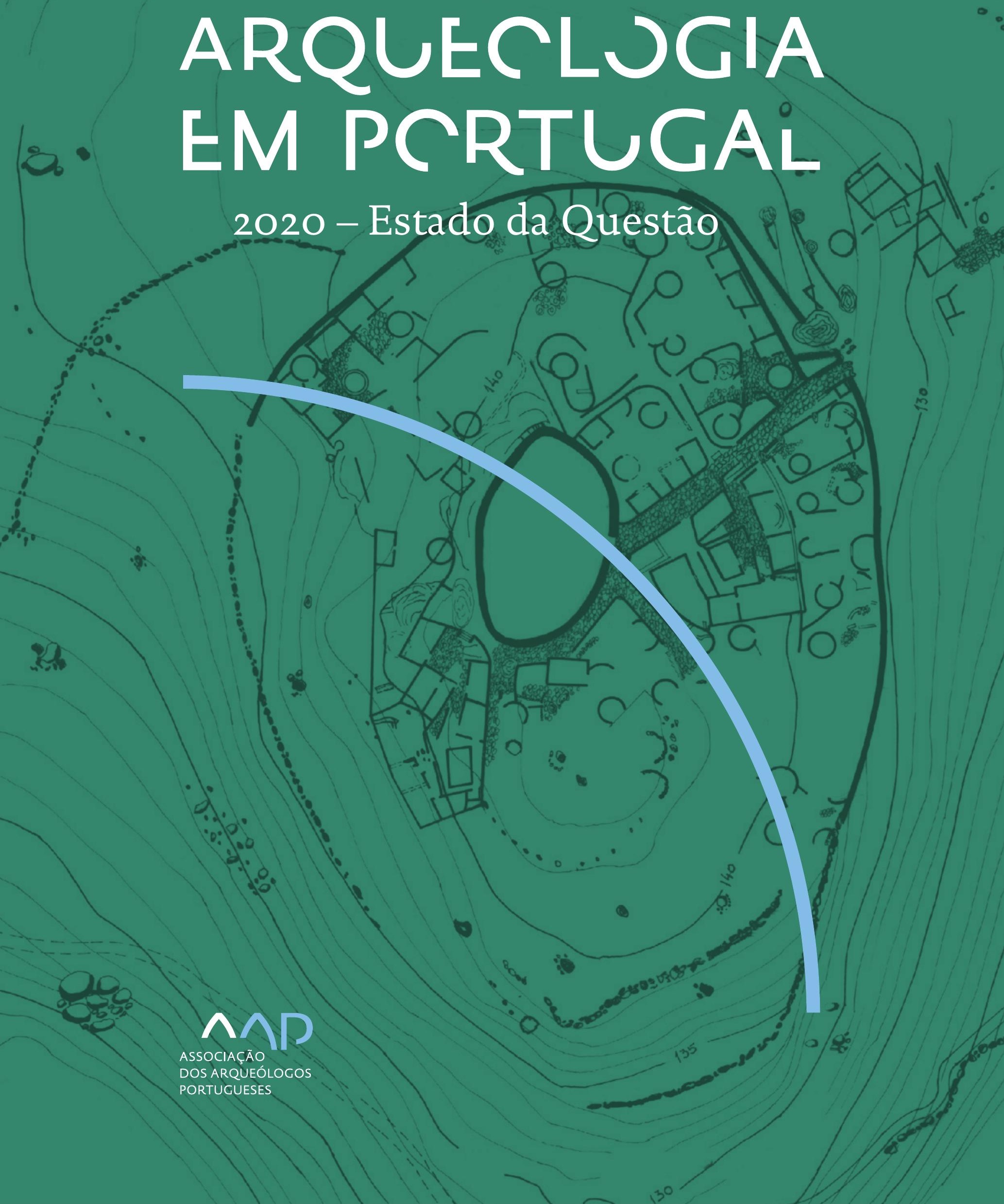


Coordenação editorial: José Morais Arnaud, César Neves e Andrea Martins Design gráfico: Flatland Design

AAP - ISBN: 978-972-9451-89-8

CITCEM - ISBN: 978-989-8970-25-1

Associação dos Arqueólogos Portugueses e CITCEM

Lisboa, 2020

O conteúdo dos artigos é da inteira responsabilidade dos autores. Sendo assim a Associação dos Arqueólogos Portugueses declina qualquer responsabilidade por eventuais equívocos ou questões de ordem ética e legal.

Desenho de capa:

Planta do castro de Monte Mozinho (Museu Municipal de Penafiel).

\section{$\hat{\wedge} \mathrm{P}$}

DOS ARQUEÓLOGOS PORTUGUESES

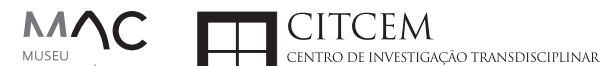
MUSEU
ARQUELLÓGICO
DO CARMO
U.PORTO

FLUP FACULDADE DE LETRAS
UNIVERSIDADE DO PORTO

Apoio

EC para a Ciência 


\section{Índice}

15 Prefácio

José Morais Arnaud

\section{Historiografia e Teoria}

17 Território, comunidade, memória e emoção: a contribuição da história da arqueologia (algumas primeiras e breves reflexões)

Ana Cristina Martins

25 Como descolonizar a arqueologia portuguesa?

Rui Gomes Coelho

41 Arqueologia e Modernidade: uma revisitação pessoal e breve de alguns aspetos da obra homónima de Julian Thomas de 2004

Vítor Oliveira Jorge

57 Dados para a História das Mulheres na Arqueologia portuguesa, dos finais do século XIX aos inícios do século XX: números, nomes e tabelas

Filipa Dimas / Mariana Diniz

73 Retractos da arqueologia portuguesa na imprensa: (in)visibilidades no feminino

Catarina Costeira / Elsa Luís

85 Arqueologia e Arqueólogos no Norte de Portugal Jacinta Bugalhão

101 Vieira Guimarães (1864-1939) e a arqueologia em Tomar: uma abordagem sobre o território e as gentes

João Amendoeira Peixoto / Ana Cristina Martins

115 Os memoráveis? A arqueologia algarvia na imprensa nacional e regional na presente centúria (2001-2019): características, visões do(s) passado(s) e a arqueologia

enquanto marca

Frederico Agosto / João Silva

129 A Evolução da Arqueologia Urbana e a Valorização Patrimonial no Barlavento Algarvio: Os casos de Portimão e Silves

Artur Mateus / Diogo Varandas / Rafael Boavida

\section{Gestão, Valorização e Salvaguarda do Património}

145 O Caderno Reivindicativo e as condições de trabalho em Arqueologia Miguel Rocha / Liliana Matias Carvalho / Regis Barbosa / Mauro Correia / Sara Simões / Jacinta Bugalhão / Sara Brito / Liliana Veríssimo Carvalho / Richard Peace / Pedro Peça / Cézer Santos

155 Os Estudos de Impacte Patrimonial como elemento para uma estratégia sustentável de minimização de impactes no âmbito de reconversões agrícolas Tiago do Pereiro

165 Salvaguarda de Património arqueológico em operações florestais: gestão e sensibilização Filipa Bragança / Gertrudes Zambujo / Sandra Lourenço / Belém Paiva / Carlos Banha / Frederico Tatá Regala / Helena Moura / Jacinta Bugalhão / João Marques / José Correia / Pedro Faria / Samuel Melro

179 Os valores do Património: uma investigação sobre os Sítios Pré-históricos de Arte Rupestre do Vale do Rio Côa e de Siega Verde José Paulo Francisco 
189 Conjugando recursos arqueológicos e naturais para potenciar as visitas ao Geoparque Litoral de Viana do Castelo (Noroeste de Portugal)

Hugo A. Sampaio / Ana M.S. Bettencourt / Susana Marinho / Ricardo Carvalhido

203 Áreas de Potencial Arqueológico na Região do Médio Tejo: Modelo Espacial Preditivo Rita Ferreira Anastácio / Ana Filipa Martins / Luiz Oosterbeek

223 Património Arqueológico e Gestão Territorial: O contributo da Arqueologia para a revisão do PDM de Avis

Ana Cristina Ribeiro

237 A coleção arqueológica do extinto Museu Municipal do Porto - Origens, Percursos e Estudos

Sónia Couto

251 Valpaços - uma nova carta arqueológica

Pedro Pereira / Maria de Fátima Casares Machado

263 Arqueologia na Cidade de Peniche

Adriano Constantino / Luís Rendeiro

273 Arqueologia Urbana: a cidade de Lagos como caso de Estudo Cátia Neto

285 Estratégias de promoção do património cultural subaquático nos Açores. O caso da ilha do Faial

José Luís Neto / José Bettencourt / Luís Borges / Pedro Parreira

297 Carta Arqueológica da Cidade Velha: Uma primeira abordagem

Jaylson Monteiro / Nireide Tavares / Sara da Veiga / Claudino Ramos / Edson Brito /

Carlos Carvalho / Francisco Moreira / Adalberto Tavares

311 Antropologia Virtual: novas metodologias para a análise morfológica e funcional Ricardo Miguel Godinho / Célia Gonçalves

\section{Didáctica da Arqueologia}

327 Como os projetos de Arqueologia podem contribuir para uma comunidade culturalmente mais consciente Alexandra Figueiredo / Claúdio Monteiro / Adolfo Silveira / Ricardo Lopes

337 Educação Patrimonial - Um cidadão esclarecido é um cidadão ativo! Ana Paula Almeida

351 A aproximação da Arqueologia à sala de aula: um caso de estudo no $3^{\circ}$ ciclo do Ensino Básico Luís Serrão Gil

363 Arqueologia 3.o - Pensar e comunicar a Arqueologia para um futuro sustentável Mónica Rolo

377 “Conversa de Arqueólogos" - Divulgar a Arqueologia em tempos de Pandemia Diogo Teixeira Dias

389 Escola Profissional de Arqueologia: desafios e oportunidades Susana Nunes / Dulcineia Pinto / Júlia Silva / Ana Mascarenhas

399 Os Museus de Arqueologia e os Jovens: a oferta educativa para o público adolescente Beatriz Correia Barata / Leonor Medeiros

411 O museu universitário como mediador entre a ciência e a sociedade: o exemplo da secção de arqueologia no Museu de História Natural e da Ciência da Universidade do Porto (MHNC-UP)

Rita Gaspar 
421 Museu de Lanifícios: Real Fábrica de Panos. Atividades no âmbito da Arqueologia Beatriz Correia Barata / Rita Salvado

427 Arqueologia Pública e o caso da localidade da Mata (Torres Novas) Cláudia Manso / Ana Rita Ferreira / Cristiana Ferreira / Vanessa Cardoso Antunes

431 Do sítio arqueológico ao museu: um percurso (também) didático Lídia Fernandes

447 Estão todos convidados para a Festa! E para dançar também... O projecto do Serviço Educativo do Museu Arqueológico do Carmo na $5^{\underline{a}}$ Edição da Festa da Arqueologia Rita Pires dos Santos

459 O “Clã de Carenque”, um projeto didático de arqueologia Eduardo Gonzalez Rocha

469 Mediação cultural: peixe que puxa carroça nas Ruínas Romanas de Troia Inês Vaz Pinto / Ana Patrícia Magalhães / Patrícia Brum / Filipa Santos

481 Didática Arqueológica, experiências do Projeto Mértola Vila Museu Maria de Fátima Palma / Clara Rodrigues / Susana Gómez / Lígia Rafael

\section{Arte Rupestre}

497 Os inventários de arte rupestre em Portugal Mila Simões de Abreu

513 O projeto FIRST-ART - conservação, documentação e gestão das primeiras manifestações de arte rupestre no Sudoeste da Península Ibérica: as grutas do Escoural e Maltravieso Sara Garcês / Hipólito Collado / José Julio García Arranz / Luiz Oosterbeek / António Carlos Silva / Pierluigi Rosina / Hugo Gomes / Anabela Borralheiro Pereira / George Nash / Esmeralda Gomes / Nelson Almeida / Carlos Carpetudo

523 Trabalhos de documentação de arte paleolítica realizados no âmbito do projeto PalæoCôa André Tomás Santos / António Fernando Barbosa / Luís Luís / Marcelo Silvestre / Thierry Aubry

537 Imagens fantasmagóricas, silhuetas elusivas: as figuras humanas na arte do Paleolítico Superior da região do Côa Mário Reis

$55^{1}$ Os motivos zoomórficos representados nas placas de tear de Vila Nova de São Pedro (Azambuja, Portugal) Andrea Martins / César Neves / José M. Arnaud / Mariana Diniz

571 Arte Rupestre do Monte de Góios (Lanhelas, Caminha). Síntese dos resultados dos trabalhos efectuados em 2007-2009 Mário Varela Gomes

599 Gravuras rupestres de barquiformes no Monte de S. Romão, Guimarães, Noroeste de Portugal Daniela Cardoso

613 Círculos segmentados gravados na Bacia do Rio Lima (Noroeste de Portugal): contributos para o seu estudo Diogo Marinho / Ana M.S. Bettencourt / Hugo Aluai Sampaio

631 Equídeos gravados no curso inferior do Rio Mouro, Monção (NW Portugal). Análise preliminar Coutinho, L.M. / Bettencourt, A.M.S / Sampaio, Hugo A.S

645 Paletas na Arte Rupestre do Noroeste de Portugal. Inventário preliminar Bruna Sousa Afonso / Ana M. S. Bettencourt / Hugo A. Sampaio 


\section{Pré-História}

661 O projeto Miño/Minho: balanço de quatro anos de trabalhos arqueológicos Sérgio Monteiro-Rodrigues / João Pedro Cunha-Ribeiro / Eduardo Méndez-Quintas / Carlos Ferreira / Pedro Xavier / José Meireles / Alberto Gomes / Manuel Santonja / Alfredo Pérez-González

677 A ocupação paleolítica da margem esquerda do Baixo Minho: a indústria lítica do sítio de Pedreiras 2 (Monção, Portugal) e a sua integração no contexto regional Carlos Ferreira / João Pedro Cunha-Ribeiro / Sérgio Monteiro-Rodrigues / Eduardo Méndez-Quintas / Pedro Xavier / José Meireles / Alberto Gomes / Manuel Santonja / Alfredo Pérez-González

693 O sítio acheulense do Plistocénico médio da Gruta da Aroeira Joan Daura / Montserrat Sanz / Filipa Rodrigues / Pedro Souto / João Zilhão

703 As sociedades neandertais no Barlavento algarvio: modelos preditivos com recurso aos SIG

Daniela Maio

715 A utilização de quartzo durante o Paleolítico Superior no território dos vales dos rios Vouga e Côa

Cristina Gameiro / Thierry Aubry / Bárbara Costa / Sérgio Gomes / Luís Luís / Carmen Manzano / André Tomás Santos

733 Uma perspetiva diacrónica da ocupação do concheiro do Cabeço da Amoreira (Muge, Portugal) a partir da tecnologia lítica Joana Belmiro / João Cascalheira / Célia Gonçalves

745 Novos dados sobre a Pré-história Antiga no concelho de Palmela. A intervenção arqueológica no sítio do Poceirão I

Michelle Teixeira Santos

757 Problemas em torno de Datas Absolutas Pré-Históricas no Norte do Alentejo Jorge de Oliveira

771 Povoamento pré-histórico nas áreas montanhosas do NO de Portugal: o Abrigo 1 de Vale de Cerdeira Pedro Xavier / José Meireles / Carlos Alves

783 Apreciação do povoamento do Neolítico Inicial na Baixa Bacia do Douro. A Lavra I (Serra da Aboboreira) como caso de estudo Maria de Jesus Sanches

797 O Processo de Neolitização na Plataforma do Mondego: os dados do Sector C do Outeiro dos Castelos de Beijós (Carregal do Sal)

João Carlos de Senna-Martinez / José Manuel Quintã Ventura / Andreia Carvalho / Cíntia Maurício

823 Novos trabalhos na Lapa da Bugalheira (Almonda, Torres Novas) Filipa Rodrigues / Pedro Souto / Artur Ferreira / Alexandre Varanda / Luís Gomes / Helena Gomes / João Zilhão

837 A pedra polida e afeiçoada do sítio do Neolítico médio da Moita do Ourives (Benavente, Portugal)

César Neves

857 Casal do Outeiro (Encarnação, Mafra): novos contributos para o conhecimento do povoamento do Neolítico final na Península de Lisboa.

Cátia Delicado / Carlos Maneira e Costa / Marta Miranda / Ana Catarina Sousa

873 Stresse infantil, morbilidade e mortalidade no sítio arqueológico do Neolítico Final/ Calcolítico ( $4^{\circ}$ e $3^{\circ}$ milénio a.C.) do Monte do Carrascal 2 (Ferreira do Alentejo, Beja) Liliana Matias de Carvalho / Sofia N. Wasterlain 
885 Come together: O Conjunto Megalítico das Motas (Monção, Viana do Castelo) e as expressões Campaniformes do Alto Minho Ana Catarina Basílio / Rui Ramos

899 Trabalhos arqueológicos no sítio Calcolítico da Pedreira do Poio Carla Magalhães / João Muralha / Mário Reis / António Batarda Fernandes

913 O sítio arqueológico de Castanheiro do Vento. Da arquitectura do sítio à arquitectura de um território João Muralha Cardoso

925 Estudo zooarqueológico das faunas do Calcolítico final de Vila Nova de São Pedro (Azambuja, Portugal): Campanhas de 2017 e 2018 Cleia Detry / Ana Catarina Francisco / Mariana Diniz / Andrea Martins / César Neves / José Morais Arnaud

943 As faunas depositadas no Museu Arqueológico do Carmo provenientes de Vila Nova de São Pedro (Azambuja): as campanhas de 1937 a 1967 Ana Catarina Francisco / Cleia Detry / César Neves / Andrea Martins / Mariana Diniz / José Morais Arnaud

959 Análise funcional de material lítico em sílex do castro de Vila Nova de S. Pedro (Azambuja, Portugal): uma primeira abordagem Rafael Lima

971 O recinto da Folha do Ouro 1 (Serpa) no contexto dos recintos de fossos calcolíticos alentejanos

António Carlos Valera / Tiago do Pereiro / Pedro Valério / António M. Monge Soares

\section{Proto-História}

987 Produção de sal marinho na Idade do Bronze do noroeste Português. Alguns dados para uma reflexão

Ana M. S. Bettencourt / Sara Luz / Nuno Oliveira / Pedro P. Simões / Maria Isabel C. Alves / Emílio Abad-Vidal

1001 A estátua-menir do Pedrão ou de São Bartolomeu do Mar (Esposende, noroeste de Portugal) no contexto arqueológico da fachada costeira de entre os rios Neiva e Cávado Ana M. S. Bettencourt / Manuel Santos-Estévez / Pedro Pimenta Simões / Luís Gonçalves

1015 O Castro do Muro (Vandoma/Baltar, Paredes) - notas para uma biografia de ocupação da Idade do Bronze à Idade Média

Maria Antónia D. Silva / Ana M. S. Bettencourt / António Manuel S. P. Silva / Natália Félix

1031 Do Bronze Final à Idade Média - continuidades e hiatos na ocupação de Povoados em Oliveira de Azeméis João Tiago Tavares / Adriaan de Man

1041 As faunas do final da Idade do Bronze no Sul de Portugal: leituras desde o Outeiro do Circo (Beja)

Nelson J. Almeida / Íris Dias / Cleia Detry / Eduardo Porfírio / Miguel Serra

1055 A Espada do Monte das Oliveiras (Serpa) - uma arma do Bronze Pleno do Sudoeste Rui M. G. Monge Soares / Pedro Valério / Mariana Nabais / António M. Monge Soares

1065 São Julião da Branca (Albergaria-a-Velha) - Investigação e valorização de um povoado do Bronze Final

António Manuel S. P. Silva / Paulo A. P. Lemos / Sara Almeida e Silva / Edite Martins de Sá

1083 Do castro de S. João ao Mosteiro de Santa Clara: notícia de uma intervenção arqueológica, em Vila do Conde Rui Pinheiro 
1095 O castro de Ovil (Espinho), um quarto de século de investigação - resultados e questões em aberto

Jorge Fernando Salvador / António Manuel S. P. Silva

1111 O Castro de Salreu (Estarreja), um povoado proto-histórico no litoral do Entre Douro e Vouga

Sara Almeida e Silva / António Manuel S. P. Silva / Paulo A. P. Lemos / Edite Martins de Sá

1127 Castro de Nossa Senhora das Necessidades (Sernancelhe): uma primeira análise artefactual Telma Susana O. Ribeiro

${ }_{1141}$ A cividade de Bagunte. O estado atual da investigação Pedro Brochado de Almeida

1153 Zoomorfos na cerâmica da Idade do Ferro no NW Peninsular: inventário, cronologias e significado Nuno Oliveira / Cristina Seoane

1163 Vasos gregos em Portugal: diferentes maneiras de contar a história do intercâmbio cultural na Idade do Ferro

Daniela Ferreira

1175 Os exotica da necrópole da Idade do Ferro do Olival do Senhor dos Mártires (Alcácer do Sal) no seu contexto regional

Francisco B. Gomes

\section{Antiguidade Clássica e Tardia}

1191 O uso de madeira como combustível no sítio da Quinta de Crestelos (Baixo Sabor): da Idade do Ferro à Romanização Filipe Vaz / João Tereso / Sérgio Simões Pereira / José Sastre / Javier Larrazabal Galarza / Susana Cosme / José António Pereira / Israel Espi

1207 Cultivos de Época Romana no Baixo Sabor: continuidade em tempos de mudança? João Pedro Tereso / Sérgio Simões Pereira / Filipe Santos / Luís Seabra / Filipe Vaz

1221 A casa romana na Hispânia: aplicação dos modelos itálicos nas províncias ibéricas Fernanda Magalhães / Diego Machado / Manuela Martins

1235 As pinturas murais romanas da Rua General Sousa Machado, n. ${ }^{5}$ 1, Chaves José Carvalho

1243 Trás do Castelo (Vale de Mir, Pegarinhos, Alijó) - Uma exploração agrícola romana do Douro

Tony Silvino / Pedro Pereira

1255 A sequência de ocupação no quadrante sudeste de Bracara Augusta: as transformações de uma unidade doméstica Lara Fernandes / Manuela Martins

1263 Os Mosaicos com decoração geométrica e geométrico-vegetalista dos sítios arqueológicos da área do Conuentus Bracaraugustanus. Novas abordagens quanto à conservação, restauro, decoração e datação Maria de Fátima Abraços / Licínia Wrench

1277 “Casa Romana” do Castro de São Domingos (Cristelos, Lousada): Escavação, Estudo e Musealização Paulo André de P. Lemos

1291 A arqueobotânica no Castro de Guifões (Matosinhos, Noroeste de Portugal): O primeiro estudo carpológico

Luís Seabra / Andreia Arezes / Catarina Magalhães / José Varela / João Pedro Tereso 
1305 Um Horreum Augustano na Foz do Douro (Monte do Castelo de Gaia, Vila Nova de Gaia) Rui Ramos

1311 Ponderais romanos na Lusitânia: padrões, formas, materiais e contextos de utilização Diego Barrios Rodríguez

1323 Um almofariz centro-itálico na foz do Mondego

Marco Penajoia

1335 Estruturas romanas de Carnide - Lisboa Luísa Batalha / Mário Monteiro / Guilherme Cardoso

1347 O contexto funerário do sector da "necrópole NO" da Rua das Portas de S. Antão (Lisboa): o espaço, os artefactos, os indivíduos e a sua interconectividade na interpretação do passado Sílvia Loja, José Carlos Quaresma, Nelson Cabaço, Marina Lourenço, Sílvia Casimiro, Rodrigo Banha da Silva, Francisca Alves-Cardoso

${ }_{1361}$ Povoamento em época Romana na Amadora - resultados de um projeto pluridisciplinar Gisela Encarnação / Vanessa Dias

1371 A Arquitectura Residencial em Mirobriga (Santiago do Cacém): contributo a partir de um estudo de caso Filipe Sousa / Catarina Felício

${ }_{1385}$ O fim do ciclo. Saneamento e gestão de resíduos nos edifícios termais de Mirobriga (Santiago do Cacém)

Catarina Felício / Filipe Sousa

1399 Balsa, Topografia e Urbanismo de uma Cidade Portuária Vítor Silva Dias / João Pedro Bernardes / Celso Candeias / Cristina Tété Garcia

1413 No Largo das Mouras Velhas em Faro (2017): novas evidências da necrópole norte de Ossonoba e da sua ocupação medieval Ricardo Costeira da Silva / Paulo Botelho / Fernando Santos / Liliana Nunes

1429 Instrumentos de pesca recuperados numa fábrica de salga em Ossonoba (Faro) Inês Rasteiro / Ricardo Costeira da Silva / Paulo Botelho

1439 A Necrópole Romana do Eirô, Duas Igrejas (Penafiel): intervenção arqueológica de 2016 Laura Sousa / Teresa Soeiro

1457 Ritual, descarte ou afetividade? A presença de Canis lupus familiaris na Necrópole Noroeste de Olisipo (Lisboa)

Beatriz Calapez Santos / Sofia Simões Pereira / Rodrigo Banha da Silva / Sílvia Casimiro / Cleia Detry / Francisca Alves Cardoso

1467 Dinâmicas económicas em Bracara na Antiguidade Tardia Diego Machado / Manuela Martins / Fernanda Magalhães / Natália Botica

1479 Cerâmicas e Vidros da Antiguidade Tardia do Edifício sob a Igreja do Bom Jesus (Vila Nova de Gaia) Joaquim Filipe Ramos

1493 Novos contributos para a topografia histórica de Mértola no período romano e na Antiguidade Tardia Virgílio Lopes

\section{8. Época Medieval}

1511 Cerâmicas islâmicas no Garb setentrional "português": algumas evidências e incógnitas Constança dos Santos / Helena Catarino / Susana Gómez / Maria José Gonçalves / Isabel Inácio / Gonçalo Lopes / Jacinta Bugalhão / Sandra Cavaco / Jaquelina Covaneiro / Isabel Cristina Fernandes / Ana Sofia Gomes 
1525 Contributo para o conhecimento da cosmética islâmica, em Silves, durante a Idade Média Rosa Varela Gomes

1537 Yábura e o seu território - uma análise histórico-arqueológica de Évora entre os séculos VIII-XII José Rui Santos

1547 A encosta sul do Castelo de Palmela - resultados preliminares da escavação arqueológica Luís Filipe Pereira / Michelle Teixeira Santos

1559 A igreja de São Lourenço (Mouraria, Lisboa): um conjunto de silos e de cerâmica medieval islâmica

Andreia Filipa Moreira Rodrigues

1571 O registo material de movimentações populacionais no Médio Tejo, durante os séculos XII-XIII. Dois casos de "sunken featured buildings", nos concelhos de Cartaxo e Torres Novas Marco Liberato / Helena Santos / Nuno Santos

1585 O nordeste transmontano nos alvores da Idade média. Notas para reflexão Ana Maria da Costa Oliveira

1601 Sepulturas escavadas na rocha do Norte de Portugal e do Vale do Douro: primeiros resultados do Projecto SER-NPVD

Mário Jorge Barroca / César Guedes / Andreia Arezes / Ana Maria Oliveira

1619 "Portucalem Castrum Novum" entre o Mediterrâneo e o Atlântico: o estudo dos materiais cerâmicos alto-medievais do arqueossítio da rua de D. Hugo, nํ. 5 (Porto) João Luís Veloso

1627 A Alta Idade Média na fronteira de Lafões: notas preliminares sobre a Arqueologia no Concelho de Vouzela

Manuel Luís Real / Catarina Tente

1641 Um conjunto cerâmico medieval fora de portas: um breve testemunho aveirense Susana Temudo

${ }_{1651}$ Os Lóios do Porto: uma perspetiva integrada no panorama funerário da Baixa Idade Média à Época Moderna em meios urbanos em Portugal

Ana Lema Seabra

1659 O Caminho Português Interior de Santiago como eixo viário na Idade Média Pedro Azevedo

1665 Morfologia Urbana: Um exercício em torno do Castelo de Ourém André Donas-Botto / Jaqueline Pereira

1677 Intervenção arqueológica na Rua Marquês de Pombal/Largo do Espírito Santo (Bucelas, Loures)

Florbela Estêvão / Nathalie Antunes-Ferreira / Dário Ramos Neves / Inês Lisboa

1691 O Cemitério Medieval do Poço do Borratém e a espacialidade funerária na cidade de Lisboa Inês Belém / Vanessa Filipe / Vasco Noronha Vieira / Sónia Ferro / Rodrigo Banha da Silva

1705 Um Espaço Funerário Conventual do séc. XV em Lisboa: o caso do Convento de São Domingos da Cidade Sérgio Pedroso / Sílvia Casimiro / Rodrigo Banha da Silva / Francisca Alves Cardoso

\section{9. Época Moderna e Contemporânea}

1721 Arqueologia Moderna em Portugal: algumas reflexões críticas em torno da quantificação de conjuntos cerâmicos e suas inferências históricas e antropológicas Rodrigo Banha da Silva / André Bargão / Sara da Cruz Ferreira

1733 Faianças de dois contextos entre os finais do século XVI e XVIII do Palácio dos Condes de Penafiel, Lisboa

Martim Lopes / Tomás Mesquita 
1747 Um perfil de consumo do século XVIII na foz do Tejo: O caso do Mercado da Ribeira, Lisboa Sara da Cruz Ferreira / Rodrigo Banha da Silva / André Bargão

1761 Os Cachimbos dos Séculos XVII e XVIII do Palácio Mesquitela e Convento dos Inglesinhos (Lisboa)

Inês Simão / Marina Pinto / João Pimenta / Sara da Cruz Ferreira / André Bargão / Rodrigo Banha da Silva

1775 "Tomar os fumos da erua que chamão em Portugal erua sancta». Estudo de Cachimbos provenientes da Rua do Terreiro do Trigo, Lisboa

Miguel Martins de Sousa / José Pedro Henriques / Vanessa Galiza Filipe

1787 Cachimbos de Barro Caulínitico da Sé da Cidade Velha (República de Cabo Verde)

Rodrigo Banha da Silva / João Pimenta / Clementino Amaro

1801 Algumas considerações sobre espólio não cerâmico recuperado no Largo de Jesus (Lisboa) Carlos Boavida

1815 Adereços de vidro, dos séculos XVI-XVIII, procedentes do antigo Convento de Santana de Lisboa (anéis, braceletes e contas)

Joana Gonçalves / Rosa Varela Gomes / Mário Varela Gomes

1837 Da ostentação, luxo e poder à simplicidade do uso quotidiano: arqueologia e simbologia de joias e adornos da Idade Moderna Portuguesa Jéssica Iglésias

1849 Os amuletos em Portugal - dos objetos às superstições: o coral vermelho Alexandra Vieira

1865 Cerâmicas de Vila Franca de Xira nos séculos XV e XVI Eva Pires

1879 «Não passa por teu o que me pertence». Marcas de individualização associadas a faianças do Convento de Nossa Senhora de Aracoeli, Alcácer do Sal Catarina Parreira / Íris Fragoso / Miguel Martins de Sousa

1891 Cerâmica de Leiria: alguns focos de produção

Jaqueline Pereira / André Donas-Botto

1901 Os Fornos na Rua da Biquinha, em Óbidos Hugo Silva / Filipe Oliveira

1909 A casa de Pêro Fernandes, contador dos contos de D. Manuel I: o sítio arqueológico da Silha do Alferes, Seixal (século XVI) Mariana Nunes Ferreira

1921 O Alto da Vigia (Sintra) e a vigilância e defesa da costa Alexandre Gonçalves / Sandra Santos

1937 O contexto da torre sineira da Igreja de Santa Maria de Loures Paulo Calaveira / Martim Lopes

1949 A Necrópole do Hospital Militar do Castelo de São Jorge e as práticas funerárias na Lisboa de Época Moderna Susana Henriques / Liliana Matias de Carvalho / Ana Amarante / Sofia N. Wasterlain

1963 SAND - Sarilhos Grandes Entre dois Mundos: o adro da Igreja e a Paleobiologia dos ossos humanos recuperados

Paula Alves Pereira / Roger Lee Jesus / Bruno M. Magalhães

1975 Expansão urbana da vila de Cascais no século XVII e XVIII: a intervenção arqueológica na Rua da Vitória no 15 a 17

Tiago Pereira / Vanessa Filipe

1987 Novos dados para o conhecimento do Urbanismo de Faro em época Moderna Ana Rosa 
1995 Um exemplo de Arqueologia Urbana em Alcoutim: o Antigo Edifício dos CTT Marco Fernandes / Marta Dias / Alexandra Gradim / Virgílio Lopes / Susana Gómez Martínez

2007 Palácio dos Ferrazes (Rua das Flores/Rua da Vitória, Porto): a cocheira de Domingos Oliveira Maia

Francisco Raimundo

2021 As muitas vidas de um edifício urbano: História, Arqueologia e Antropologia no antigo Recreatório Paroquial de Penafiel Helena Bernardo / Jorge Sampaio / Marta Borges

2035 O convento de Nossa Senhora da Esperança de Ponta Delgada: o contributo da arqueologia para o conhecimento de um monumento identitário João Gonçalves Araújo / N’Zinga Oliveira

2047 Arqueologia na ilha do Corvo... em busca da capela de Nossa Senhora do Rosário Tânia Manuel Casimiro / José Luís Neto / Luís Borges / Pedro Parreira

2059 Perdidos à vista da Costa. Trabalhos arqueológicos subaquáticos na Barra do Tejo Jorge Freire / José Bettencourt / Augusto Salgado

2071 Arqueologia marítima em Cabo Verde: enquadramento e primeiros resultados do projecto CONCHA

José Bettencourt / Adilson Dias / Carlos Lima / Christelle Chouzenoux / Cristóvão Fonseca / Dúnia Pereira / Gonçalo Lopes / Inês Coelho / Jaylson Monteiro / José Lima / Maria Eugénia Alves / Patrícia Carvalho / Tiago Silva

2085 Trabalhos arqueológicos na Cidade Velha (Ribeira Grande de Santiago, Cabo Verde): reflexões sobre um projecto de investigação e divulgação patrimonial André Teixeira / Jaylson Monteiro / Mariana Mateus / Nireide Tavares / Cristovão Fonseca / Gonçalo C. Lopes / Joana Bento Torres / Dúnia Pereira / André Bargão / Aurélie Mayer / Bruno Zélie / Carlos Lima / Christelle Chouzenoux / Inês Henriques / Inês Pinto Coelho / José Lima / Patrícia Carvalho / Tiago Silva

2103 A antiga fortificação de Quelba / Khor Kalba (E.A.U.). Resultados de quatro campanhas de escavações, problemáticas e perspectivas futuras Rui Carita / Rosa Varela Gomes / Mário Varela Gomes / Kamyar Kamyad

2123 Colónias para homens novos: arqueologia da colonização agrária fascista no noroeste ibérico Xurxo Ayán Vila / José Mạ . Señorán Martín 


\title{
A NECRÓPOLE ROMANA DO EIRÔ, DUAS IGREJAS (PENAFIEL): INTERVENÇÃO ARQUEOLÓGICA DE 2016
}

\author{
Laura Sousa $^{\mathrm{I}}$, Teresa Soeiro $^{2}$
}

\begin{abstract}
RESUMO
Em 2016, a construção do Centro Paroquial de Duas Igrejas (Penafiel) proporcionou a (re)escavação, pelo Museu Municipal de Penafiel, de uma das necrópoles romanas conhecidas na freguesia, lugar do Eirô. Abílio Miranda publicou a primeira notícia em 1941, reportando-se ao achamento ocasional de enterramentos, num terreno entre a igreja e o cemitério. Continham cerâmica comum romana e um anel decorado, materiais que, sem destrinça, deram entrada no Museu. Com a presente intervenção, recuperaram-se as estruturas tumulares remanescentes daquela ocorrência e escavaram-se, integral ou parcialmente, mais seis sepulturas de inumação preservadas, contendo cerâmica, pregadura de calçado com vestígios de tecido e numismas, permitindo uma nova leitura do sítio e a datação destes enterramentos, atribuídos ao terceiro quartel do século IV d.C.

Palavras-chave: Necrópole romana, Sepulturas de inumação, Século IV, Duas Igrejas/Penafiel, Museu Municipal de Penafiel.
\end{abstract}

\begin{abstract}
The (re)excavation, in 2016, by Penafiel's Municipal Museum, of one of the known parish's Roman necropolis at Eirô hamlet, was facilitated by the construction of the Duas Igrejas Parish Centre. In 1941, Abílio Miranda published the first news referring the casual finding of archeological burials in a ground between the church and the graveyard. Roman coarse wares and an ornamented ring were found there. These materials entered the Museum unrecorded. In this intervention the remaining grave structures of that occurrence were uncovered. Six more preserved inhumation tombs were partially or fully excavated that contained pottery, hobnails with fabric remains, and coins. It allowed for a new interpretation of the site and these burials datation, attributed to the $4^{\text {th }}$ century A.D.
\end{abstract}

Keywords: Roman necropolis, Inhumation tombs, $4^{\text {th }}$ century, Duas Igrejas/Penafiel, Municipal Museum of Penafiel.

\section{O SÍTIO ARQUEOLÓGICO}

Abílio Miranda (1893-1962), estudioso do património local e director da Biblioteca-Museu Municipal de Penafiel, noticiou, no início dos anos Quarenta, o achado de duas necrópoles romanas na freguesia de Duas Igrejas (Penafiel). No primeiro artigo, publicado em 1941 (Miranda, 1941), referiu-se à descoberta casual, que lhe fora de imediato comunicada pelo pároco, resultante de obras em curso junto da Igreja. Assim, teve ensejo de se deslocar ao lugar do
Eirô, visionar a intervenção e recolher algum espólio para o futuro Museu, nomeadamente vasos cerâmicos e um anel de azeviche (MMPNF/4655). A outra ocorrência sucedera em 1933, ao abrir os alicerces para a Escola Primária, no lugar de Antas, $300 \mathrm{~m}$ a SO da Igreja, tendo sido avisado pelo mesmo sacerdote, ainda a tempo de observar "uma ou duas cavidades de sepulturas" (Miranda, 1942, p. 65). Dele recebeu, para acervo museológico, cerâmicas romanas e um anel em bronze (MMPNF/4656), cuja mesa ostenta o conhecido tema clássico do

\footnotetext{
1. CITCEM - Centro de Investigação Transdisciplinar «Cultura, Espaço e Memória»; laura_sousa@hotmail.com

2. CITCEM - Centro de Investigação Transdisciplinar «Cultura, Espaço e Memória»; teresasoeiro@sapo.pt
} 
"casal afrontado» (Cravinho, 2014, p. 363). Provirão também desta necrópole as 41 moedas do século IV (MMPNF/2949-2950, 2952-2989 e 4334) estudadas por Isabel Pereira (1975) e um estilete de bronze (MMPNF/4687) referido por Pinho Brandão (1961, p. 30). O enquadramento do sítio e a publicação dos materiais cerâmicos (MMPNF/2906-2920; 2922-2933 e 5311), que integram a colecção apenas com indicação da freguesia (não especificando qual dos cemitérios e conjunto funerário), bem como dos anéis e estilete, foi realizada pela segunda autora desta comunicação, em 1984 (Soeiro, 1984, pp. 89-95).

Estando a área sob vigilância desde então, a construção do novo Centro Paroquial de Duas Igrejas motivou a realização de sondagens arqueológicas, em 2015, a cargo do Museu e dirigidas pela primeira autora (DRCN-DSBC/2015/495). Foi confirmado o interesse patrimonial do espaço, procedendo-se, em 2016, ao alargamento da escavação em área, na plataforma superior, coincidente com as descrições de Abílio Miranda. Aqui, para além do reconhecimento de algumas das estruturas exumadas em 1941, identificaram-se novos enterramentos, preservados, possibilitando a (re)interpretação da necrópole e datação de pelo menos um período de utilização, o que permite o cotejo com outras congéneres, estudadas na área de Penafiel e região envolvente ${ }^{3}$ (Figura 1).

\section{O LUGAR}

A necrópole do Eirô (41.185625-8.269802) está localizada numa área aplanada do centro da freguesia de Duas Igrejas, que pouco ultrapassa os $400 \mathrm{~m}$ de altitude, na mancha de "granitos monzoníticos, porfiróides de duas micas, essencialmente biotíticos" (CGP - Folha 9-D). Contornam esta rechã os altos de Marecos (449m), a Poente, e os da Brenha (477m) e Chocal (589m) a NE-E, tendo a Sul o planalto de Luzim $(556 \mathrm{~m})$. Elevações inabitadas, foram até ao passado século áreas de pastoreio e recolha de lenha, e delas descem águas que alimentam córregos e nascentes, fundamentais ao assentamento e cultivo do solo em altitude intermédia. A sede da paróquia de Santo Adrião de Canas, instalada, na Idade Média,

3. Agradecemos a Rui Centeno a classificação das moedas, apesar da dificuldade decorrente de ainda não terem sido objecto de qualquer tratamento, bem como as sugestões de interpretação, a Rui Oliveira a realização das estampas e a Eduardo Cunha a fotografia de artefactos. entre campos agrícolas, num local mais baixo, a Sul, foi transferida, por 1564, para o lugar do Eirô (Santos, 1973, pp. 540-541; R., 1973), desafogado e bem conectado, onde existia a ermida de Santa Maria e, antes dela, a necrópole romana e, provavelmente, o respectivo povoado aberto/aldeia, com o qual também se relacionará o espaço funerário de Antas. Quase contígua à nova igreja foi erguida, antes dos meados do século XVIII, a residência paroquial, com campo do passal e horta (Cardoso, 1751, p. 403), que interferiram com os enterramentos romanos, pois um dos escavados (S. 8) está coberto pelo alicerce desta parede. Também o muro periférico do actual cemitério, datado de 1886 e implantado a Este do passal, cortou o sítio, sendo comum surgirem materiais arqueológicos dispersos ao preparar os funerais. Em Duas Igrejas cruzam-se caminhos naturais de passagem, quer os que ligam as terras baixas das margens do Sousa e Cavalum (W) ao vale do Tâmega (E), à altura da ponte romana de Canaveses, quer o que da Portela de Santa Marta (N) se dirige a S, pelos altos de Luzim até às passagens do Tâmega e Douro, ou por Rans e o vale da ribeira da Camba, em cota baixa, até Entre-os-Rios. Em qualquer destes percursos se encontram sítios arqueológicos de época romana, muitos coetâneos da necrópole em estudo (Soeiro, 1984 e 2018; PDM - Carta do Património).

\section{O ACHADO DE 1941 E A INTERVENÇÃO DE 2016}

Abílio Miranda (1941) descreve o sítio como "uma vasta necrópole mixta de sepulturas circulares, rectangulares e uma antropomórfica aberta na rocha». Parco e por vezes desconcertante nos detalhes, individualizou seis destas sepulturas: uma antropomórfica aberta na rocha, quatro rectangulares "abertas em terra, mas aparelhadas à volta com pedra», que «mediam aproximadamente dois metros de comprido por sessenta centímetros de largo" e "eram tôdas forradas, pela parte interior, de tabuões de madeira", e uma "de menores dimensões, que serviu a uma criança». Deixamos de lado as covas circulares, que diz vazias, e as demais cavidades irregulares do saibro, possível resultado da plantação de árvores e colocação de estruturas efémeras no campo do passal. Pelo contrário, valorizamos a sua referência ao facto de uma sepultura ser aberta na rocha e simultaneamente conter espólio (romano), condições que se repetiram nas S. 4 e S. 5, de 2016, contribuindo 
assim para esclarecer o equívoco gerado por aquela notícia e exacerbado em notas posteriores, com larga repercussão na historiografia das sepulturas (antropomórficas) abertas na rocha, medievais (Barroca, 2010-2011, p. 135).

A intervenção de 2016 estendeu-se pela plataforma sensivelmente horizontal entre a igreja e o muro do cemitério (c. $\left.325 \mathrm{~m}^{2}\right)$, à face da rua da Liberdade, e permitiu identificar: cinco sepulturas romanas preservadas (S. 1 a S. 5), das quais uma não escavada na totalidade por estar sob o passeio da via pública (S. 3); uma sepultura (S. 8) perturbada pela construção da antiga Casa Paroquial, cujo alicerce integrava também parte de uma mó giratória em granito de moinho manual romano (MMPNF/14483) e, na vala de fundação, uma moeda de Constâncio II (MMPNF/14424); cinco das seis sepulturas referidas por Abílio Miranda, agora renumeradas (S. 6, 7 e 9 a 11) (Figura 2).

\section{A NECRÓPOLE E AS SEPULTURAS}

A necrópole do Eirô ficou delimitada em escavação apenas no sentido Sudeste, pela confirmação da não existência de elementos cemiteriais numa faixa de $\pm 12 \mathrm{~m}$ antes do declive do terreno. No sentido oposto, sabemos que avança para a via pública (veja-se $S$. 3); em direção SO-NE, foi cortada tanto pelo adro e casa paroquial (S. 8), como pelo atual cemitério (zona escavada em 1941). Estava instalada numa área aplanada, certamente com pouca potência de terra sobre o substrato, constituído sobretudo por alterite de granito, fácil de escavar com instrumentos de ferro mas suficientemente estável para as covas não necessitarem de estrutura de contenção. As marcas de corte e desbaste indiciam a morfologia da lâmina e a direcção dos golpes dos instrumentos utilizados para as abrir. Porém, em alguns pontos este saibro muito alterado dá lugar a outro, duro, com grânulos de quartzo e feldspato de maior dimensão, mais difícil de aprofundar. A gradação prossegue até às sepulturas abertas na própria rocha, situação provavelmente não desejada e mesmo evitada quando o afloramento ficava visível, que resultou em sepulcros pouco profundos (S. $4=0,4 \mathrm{Om} \mathrm{e} \mathrm{S.} 5=0,25 \mathrm{~m}$ escavados) e com os limites verticais e o fundo irregulares e toscos (Figura 3).

Apesar destas contingências, dez dos enterramentos reconhecidos, com diferente tipologia construtiva, estão organizados sensivelmente na mesma orientação, NE-SO, sem sobreposições e com interceções tangenciais (nas S. 2 e 3, pela abertura da S. 10, e na S. 5, pela S. 8). Nenhum dos escavados em 2016, covas simples distribuídas pela área com pouca potência de solo arável, conservava a cobertura, se existiu. Pelo contrário, os descobertos em 1941, de construção pétrea e implantados numa zona mais funda do terreno (S. 6,7 e 11), estariam capeados com "cascões de pedra» granítica, como registou Abílio Miranda. Contudo, as cotas superiores de uns e outros são idênticas, pelo que também estas coberturas poderiam não ter impacto à superfície, colocando-se mais uma vez a questão do reconhecimento externo, que evitasse violações inadvertidas e facilitasse a identificação do defunto para a aproximação dos familiares à campa em momento de celebração.

Faremos, de seguida, a caracterização sumária dos enterramentos. Para cada um são indicadas as dimensões (compr. x larg.) à superfície do natural e na base da cova (sup./base), seguidas da profundidade medida a partir do natural, embora, à época, este estivesse certamente recoberto por terra, o que ampliaria este valor, em alguns casos manifestamente insuficiente para se realizar qualquer deposição de um corpo. Como é normal no Noroeste, não foram encontrados vestígios osteológicos.

S. 1 - Cova sub-retangular aberta no saibro $(1,66 /$ $1,32 \mathrm{~m} \times 0,90 / 0,80 \mathrm{~m} \times 0,56 \mathrm{~m}$ ), com paredes irregulares e ângulos arredondados, fundo horizontalizado. O espólio cerâmico está quase todo agrupado a $\mathrm{SO}$, com dois pratos pousados no fundo, encaixados, e sobre eles o copo, ladeado pelos outros dois pratos e o jarro; a meio da linha central encontra-se a bilha; as 8 moedas agrupam-se a N, sobre o lado. Os vasos fechados foram propositadamente deitados (todos no mesmo sentido), para sobre eles ser depositado o corpo, simplesmente ou numa padiola à qual atribuir as ferragens em L e prego. Esta distribuição sugere que a cabeça ficaria a NE e as moedas ao lado (?) do defunto. Na terra de enchimento, a cota superficial, havia fragmentos de pelo menos outros três vasos (jarro, bilha e copo, 14391-14393), bastante incompletos, quiçá peças partidas e abandonadas em 1941, arrastadas pelas movimentações de terra posteriores (Figura $4 \mathrm{e} 9$ ).

S. 2 - Cova sub-retangular aberta no saibro $(1,84 /$ 1,72m x 0,92/o,70m x 0,52m), com paredes rectas e fundo aplanado. Defunto com a cabeça a SO, espólio depositado sobre o fundo, à esquerda da linha longitudinal, começando pelas moedas, a ladear o ombro (?), seguidas de um púcaro, três pratos e 
novo púcaro, distribuindo-se o restante vasilhame, tombado, em redor dos pés, documentados a NE pela presença de 63 tachas de calçado com cabeça em calote esférica, amontoadas, com vestígios de tecido (da mortalha?), que envolveria o corpo, certamente também vestido (Figura 5 e 10).

S. 3 - Cova sub-retangular aberta no saibro, parcialmente escavada ( $1,55 / 1,50 \mathrm{~m}$ x ? x o,57m), com paredes algo encurvadas e fundo aplanado com concavidades junto dos dois ângulos expostos, distando entre si cerca de 1,20m. Deposição orientada com a cabeça a NE (?). Espólio depositado no fundo, moeda e um grupo de 18 tachas de calçado com vestígios de tecido a SO (11 em outros dois grupos); uma bilha, deitada, ao centro, e os restantes vasos na outra metade da sepultura (sob a cabeça e o dorso?), alguns intencionalmente sobrepostos. As cavidades nos ângulos e a mortalha apontam para o uso de padiola/ leito (ou caixão com pés de apoio) (Figura 11).

S.4-Cova sub-retangular/trapezoidal aberta na rocha, mais estreita a SO (1,70/1,44m x $\pm 1,10 / 0,70 \mathrm{~m}$ x o,40m). Espólio depositado no fundo aplanado, próximo da linha média longitudinal, com os dois vasos fechados deitados para ficarem sensivelmente à altura dos pratos, facilitando a sobreposição do cadáver, para a orientação do qual não temos argumento a não ser a maior largura dos ombros, a $\mathrm{NE}$ (Figura 12).

S. 5 - Cova sub-retangular irregular aberta na rocha $(1,92 / 1,72 \mathrm{~m} \times 0,80 / 0,72 \mathrm{~m} \times 0,25 \mathrm{~m})$, cabeceira a NE, com concavidades junto dos ângulos, na proximidade das quais foi recolhida a moeda. Espólio depositado no fundo aplanado, a maioria na linha média da metade inferior, com os vasos fechados deitados, a que se segue uma mancha com 83 tachas, muitas patenteando marcas de tecido bem visíveis (Figura 6). Um jarro, muito incompleto, e 8 tachas estão próximo da parede NO (Figura 13).

S. 8 - Cova sub-retangular aberta no saibro, com um topo destruído pela parede da antiga Casa Paroquial (? x c.1,05/1,12 x c.0,48m). Poderia ser estruturada com lajes graníticas na vertical, adossadas ao saibro, reduzindo a largura, o que a aproxima às de 1941. Recolheram-se 32 tachas, muitas com vestígios de tecido, e um copo incompleto.

Das sepulturas noticiadas por Abílio Miranda, em 1941, foram analisadas as seguintes estruturas, concentradas a Norte, no ângulo formado pela rua e o muro do cemitério.

S. 6 - Sepultura retangular com caixa pétrea $(1,90 /$

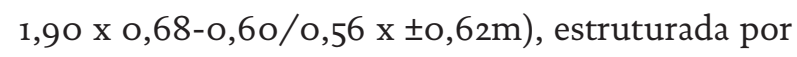
seis lajes de granito, com pedra miúda e saibro nos interstícios, usa o saibro como fundo. O lado SO está encostado ao afloramento, cortado para receber a laje. Estas são pouco trabalhadas e poderiam obter-se neste local, mesmo à superfície: trata-se dos cascões de pedra com que os trabalhadores de 1941 se depararam (Figura 7).

S. 7 - Sepultura retangular com caixa pétrea $(1,63 /$ $1,58 \times 0,58 / 0,62 \times \pm 0,52 \mathrm{~m}$ ), estruturada com sete lajes de granito e duas pedras que nivelam o topo NE, onde encosta ao afloramento, podendo assim receber mais facilmente a cobertura. Saibro do fundo demasiado aprofundado em 1941, abaixo do limite das lajes (Figura 8).

S. 9 - Sepultura retangular escavada na rocha $(1,70 /$ 1,64 x o,63/o,6o x 0,04 a NE e o,24m a S). Corresponderá à sepultura "antropomórfica escavada na rocha».

S. 10 - Sepultura (?) quadrangular escavada no saibro ( $1,60 \times 1,20 \times 0,40 m)$. Cortou marginalmente a S. 2 e S. 3, e será a «de menores dimensões, que serviu a uma criança».

S. 11 - Sepultura retangular muito destruída (aprox. 1,80 x 0,74-0,80 x 0,6om), identificável pelos cortes no saibro onde encostariam as lajes da caixa, como nas 6 e 7 .

S. 12 - Interfaces na área escavada em 1941, junto do muro do Cemitério, poderão corresponder a esta sepultura (retangular e de caixa com lajes?).

\section{OS MATERIAIS DEPOSITADOS}

Abílio Miranda diz-nos que nas sepulturas estruturadas com lajes havia louça. Mas, apenas destaca o espólio de duas outras: na chamada antropomórfica, foi recolhido um anel de azeviche e, junto dos membros inferiores, "uma anforeta de uma asa e uma ampula" (púcaro e bilha), existindo ainda pregos e «bastante carda grossa, que pertencia ao calçado do cadáver»; a de criança conteria objectos cerâmicos "de uma interessante miniatura", entre os quais um jarro com bocal trilobado (Miranda, 1941, p. 28-29). No Museu, apenas o anel de azeviche pode ser isolado. Datável do Baixo Império, tem aro de decoração torsa, a alargar para a mesa, saliente, onde se abriu, a picotado, um motivo semi-circular preenchido com linhas radiais (Soeiro, 1984, p. 90-91). Fabrico provincial, terá origem nas oficinas de Bracara Augusta (Cravinho, 2014, p. 599). 
Todos os enterramentos escavados (2016) apresentavam materiais cerâmicos, por vezes acompanhados de moedas. Trata-se de olaria de fabrico local/ regional, com uma panóplia de formas limitada: jarro trilobado (bico unido, asa sem dedeira), bilha (bocal estreito, asa com dedeira, pança elíptica ou cortada), púcaro de perfil em $\mathrm{S}$ (vários tamanhos, decoração de caneluras finas a marcar o colo), copo de perfil em S e prato/prato de lume. São conjuntos vulgares nas necrópoles baixo-imperiais de Penafiel (Soeiro, 1984, 2009-2010, 2015; Pinto, 1998) e por toda a bracarense (Tabela 1 ).

Nos jarros trilobados e pratos, as pastas apresentam texturas fortemente arenosas, com grãos brancos muito visíveis, e superfícies ásperas ou pouco alisadas, em tons de castanho, do claro ao enegrecido pelo uso ao lume. A S. 5 é um expoente deste fabrico grosseiro e mau acabamento do jarro e pratos, mesmo do copo, cujo alisamento exterior não encobre as irregularidades da parede. Grande semelhança entre si mostram os pequenos pratos da S. 1 (Figura 9: 4) e S. 4 (Figura 12: 3 e 4), pouco ou nada usados, em tom bege acastanhado, alisados, que seguramente saíram das mãos do mesmo artífice. Outros, com fortes marcas de terem estado ao lume, apesar de deformados na cozedura, serviram em vida e, por fim, seguiram para a cova (Figura 10: 8 e 12: 5).

De entre a olaria usada ao fogo sobressai uma peça da S. 1 (Figura 9: 5), com parede reta esvasada e lábio boleado com ligeiro espessamento, facetado. Somos levados a colocá-la como tampa por o disco central (como que fundo) apresentar externamente, ao centro, dois arranques de uma asa de fita. Outras particularidades são a argila babada na mal conseguida união "fundo"/parede, a diferente coloração das partes, o perfil irregular e a fuligem interior. Partida a asa, podia ter sido depositada na sepultura como prato.

Um outro grupo, de vasos para líquidos - bilhas, púcaros e copos -, apresenta-se geralmente sem fuligem, fabricado numa pasta arenosa de calibre menos grosseiro, por vezes com desengordurante cerâmico, bem cozida. Tem perfis regulares, tom castanho/alaranjado e superfícies cuidadas no exterior, incluindo dos fundos, e interior do bordo. Os púcaros médios da S. 2 e S. 3 (Figuraio: 4 e 11: 3) mostram fuligem exterior, concentrada no lado oposto à asa, como é típico dos jarros, encostados ao lume para aquecer o conteúdo. Pelo menos num caso, o copo da S. 3 (Figura 11: 4), verificou-se que o bojo apresenta um orifício subcircular aberto intencionalmente, após a cozedura, talvez aquando do depósito, prática recorrente nas necrópoles escavadas em Penafiel.

Apesar de sensivelmente sincrónico, o espólio da S. 3 (Figura 11), suscitou, desde o momento do achado, o reconhecimento de diferença por uma maior delicadeza na feitura e aparência de algumas vasilhas: a bilha era de tamanho pequeno, morfologia cuidada, pasta comparativamente depurada e bom alisamento; havia também um pratel e uma tacinha (a formar serviço?) de superfícies castanho/alaranjadas, bem alisadas e, no caso da segunda, cobertas por espessa aguada do mesmo tom em todo o interior e numa faixa exterior a partir do lábio. Teria sido, talvez, outro conjunto assim que levou Abílio Miranda a identificar uma das sepulturas (S. 10, ao lado desta?) como de criança, situação que lembra a da escavação da sepultura 4 (1974) do Castro de Monte Mozinho, pequena inumação de meados ou 2. a $^{\text {a }}$ made do século IV, com formas cerâmicas de tamanho bastante reduzido e fabrico relativamente apurado, que levou Carlos Alberto Ferreira de Almeida a sugerir parecer-lhe infantil (Almeida, 1974, p. 44-45).

Na S. 5, além da cerâmica e moeda, havia um fragmento mínimo de vaso de vidro incolor com leve curvatura e espessura inferior a 1mm. Já a S. 4 continha um pequeno fragmento indeterminado de bronze, recto e com secção circular.

As moedas, treze depositadas em quatro das sepulturas e duas recolhidas nas UE envolventes, apresentam uma cronologia bastante homogénea, sendo

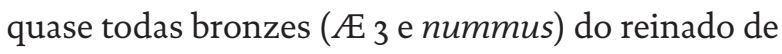
Constâncio II, com sinais de alguma circulação, o que aponta para a datação dos enterramentos no $3 .^{.}$ quartel do século IV. Na S. 1, surgiram oito, amontoadas, na metade da sepultura onde não havia outro espólio, ao lado da cabeça/peito do defunto, muito juntas, talvez contidas em bolsa. São cunhagens de $335-340$ a $357-361$. A S. 2 forneceu três, sendo as duas legíveis também de Constâncio II (355-357), assim como a da S. 5; a da S. 3, colocada junto das tachas, muito deteriorada, foi atribuída ao século IV. Os dois exemplares recolhidos na estratigrafia envolvente pertencem ao mesmo reinado. $\mathrm{Na}$ anterior escavação (1941), não ficou notícia do aparecimento de numismas. Já na necrópole do lugar de Antas havia moedas nos enterramentos, as quais deram entrada no Museu, juntamente com a cerâmica e o anel. São 41 exemplares, sem indicação dos conjun- 
tos funerários. Inventariadas por Isabel Pereira (Pereira, 1975), a sua cronologia coincide com a anterior, prolongando-se, porém, até ao final do século IV (394-395), com possível circulação no seguinte.

Em síntese, estaremos perante uma das necrópoles desta aldeia estabelecida em área aberta, na interface do monte com as melhores terras agrícolas, em local de passagem. A existência da área funerária de Antas, a 3oom, sugere uma localização do povoado no espaço intermédio, desde a época moderna centrado na igreja paroquial. As sepulturas escavadas, do $3 .^{\circ}$ quartel do século IV, são inumações em cova retangular, onde o falecido, amortalhado (sobre o calçado) seria depositado em decúbito dorsal (?), maioritariamente com a cabeça a NE, sobre uma padiola/leito ou caixão (suportes a pousar nas concavidades dos ângulos), ou directamente por cima das vasilhas, com o remanescente do banquete fúnebre, distribuídas no fundo, por vezes empilhadas e com os vasos fechados deitados para nivelamento. Não havia objectos de adorno da pessoa e vestuário (excepto o de S. 4 ?), sendo os conjuntos bastante uniformes e bem mais pobres do que os dos níveis sincrónicos das necrópoles penafidelenses de Montes Novos e Monteiras, com as quais tem paralelos e para cuja discussão remetemos (Pinto, 1998; Soeiro, 2009-2010, 2015). Em Bracara Augusta, por esta época, já escassos artefactos se depositavam nas inumações (Braga, 2018, p. 417). As sepulturas de 1941, com caixa de lajes pétreas, diferenciam-se destas (Arezes, 2017, p. 195), ainda que sigam o alinhamento e contivessem cerâmica comum, não sendo possível precisar a datação, que poderá chegar ao século V, como as da área de Antas, momento em que a ocupação disseminada pelo território continuava densa e variada (Soeiro, 2018).

\section{BIBLIOGRAFIA}

ALMEIDA, Carlos Alberto Ferreira de (1974) - Escavações no Monte Mozinho (19749. Penafiel: Centro Cultural Penafidelis.

AREZES, Andreia (2017) - O mundo funerário na antiguidade tardia em Portugal: as necrópoles dos séculos V a VIII. Porto: CITCEM/Edições Afrontamento.

BARROCA, Mário Jorge (2010-2011) - Sepulturas escavadas na rocha de Entre Douro e Minho. Portvgalia. Porto. Nova Série. 31-32, pp. 115-182.

BRAGA, Cristina Maria Vilas Boas (2018) - Morte, memória e identidade. Uma análise das práticas funerárias de
Bracara Augusta. Braga: Universidade do Minho (tese de doutoramento).

BRANDÃO, D. de Pinho (1961) - Atramentarium e stilus do Museu de Penafiel. Lucerna. Porto, 1:1, pp. 29-34.

CARDOSO, Luiz (1751) - Canas de Duas Igrejas. In Diccionario geografico. Lisboa: Na Regia Officina Sylviana, e da Academia Real. Tomo 2, p. 403.

CRAVINHO, Graça Maria Pombo (2014) - Glíptica romana em Portugal. Santiago de Compostela: USC-Faculdad de Xeografia e Historia (tese de doutoramento).

MIRANDA, Abílio (1941) - Sepulturas abertas na rocha. Douro Litoral. Porto. 1. érie, 3, pp. 27-29.

MIRANDA, Abílio (1942) - Anel de Casados. Douro Litoral. Porto. 1. érie, 5, pp. 65-66.

PEREIRA, Isabel (1975) - Moedas tardo-romanas da necrópole das Duas Igrejas (concelho de Penafiel). Conimbriga. Coimbra. 14, pp. 185-197.

PINTO, Gilda Correia (1998) - A necrópole romana de Montes Novos/Croca, Penafiel. Cadernos do Museu. Penafiel: Museu Municipal, vol. 2, pp. 187-240.

R, A. M. (1973) - Comenda de Duas Igrejas. Penafiel. Boletim de Cultura da Câmara Municipal. Penafiel. 2, pp.6o-67.

SANTOS, Cândido Augusto Dias dos (1973) - Censual da Mitra do Porto. Subsídios para o estudo da diocese nas vésperas do Concílio de Trento. Porto: Câmara Municipal do Porto.

SOEIRO, Teresa (1984) - Monte Mozinho. Apontamentos sobre a ocupação entre Sousa e Tâmega em época romana.

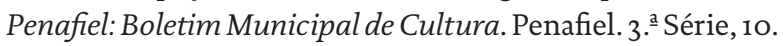

SOEIRO, Teresa (2009-2010) - Necrópole romana de Monteiras (Bustelo-Penafiel). Cadernos do Museu. Penafiel: Museu Municipal, vol.12/13, pp. 5-221.

SOEIRO, Teresa (2015) - A preferência pela inumação nas necrópoles romanas dos sécs. III-IV d.C. do Município de Penafiel (Norte de Portugal). Actas do II Congresso Internacional sobre Arqueologia de Transição. Évora: UE/CHAIA, pp. 159-174.

SOEIRO, Teresa (2018) - O Castro de Monte Mozinho (Penafiel, Porto) e o seu aro em época tardo-romana e tardo-antiga, In LÓPEZ QUIROGA, Jorge (coord.) - In tempore sueborum. Ourense: Deputación Provincial de Ourense, pp. 211-216. 


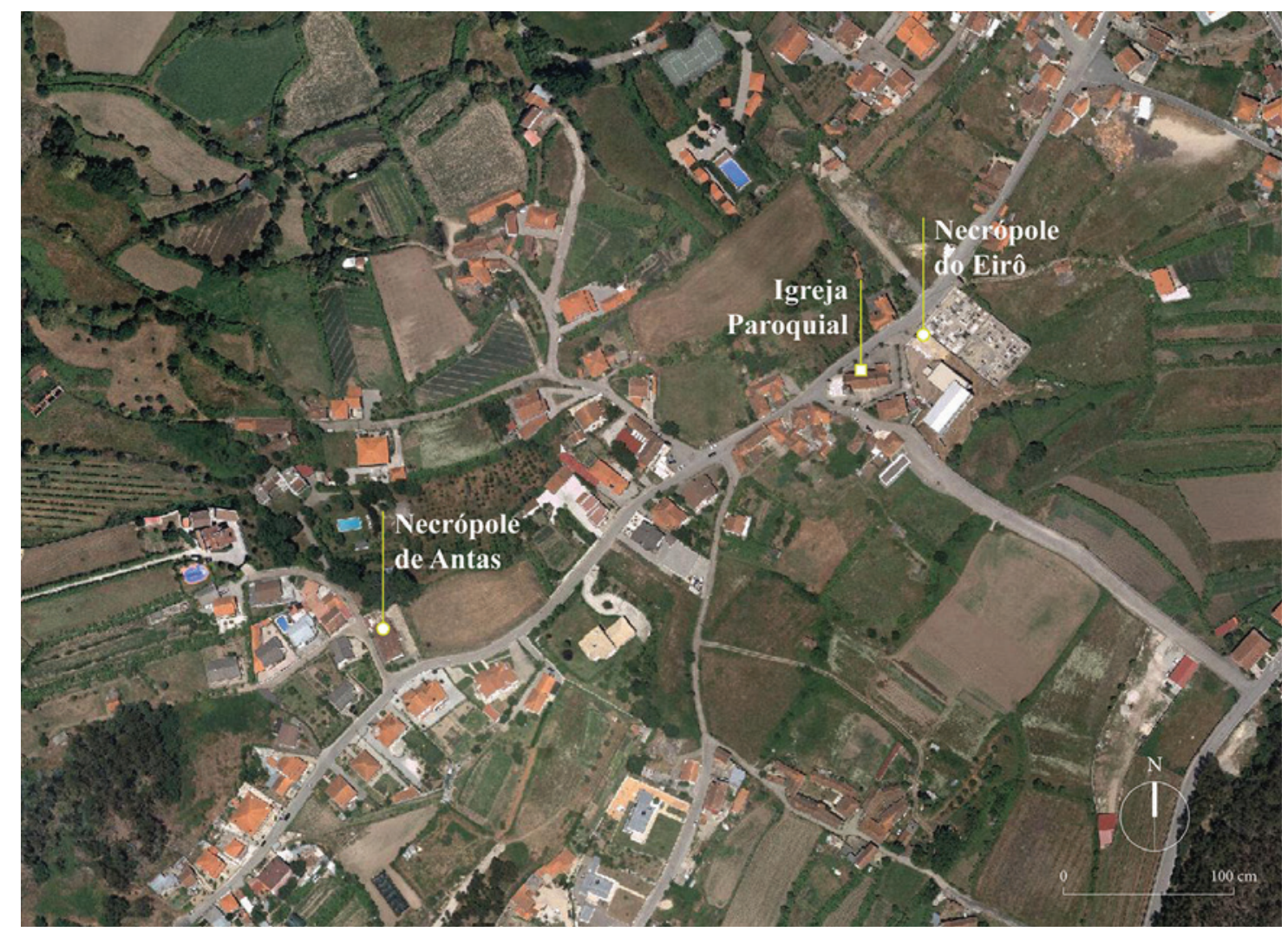

Figura 1 - Necrópoles romanas do Eirô e de Antas (Duas Igrejas): levantamento aerofotogramétrico (CMPNF).

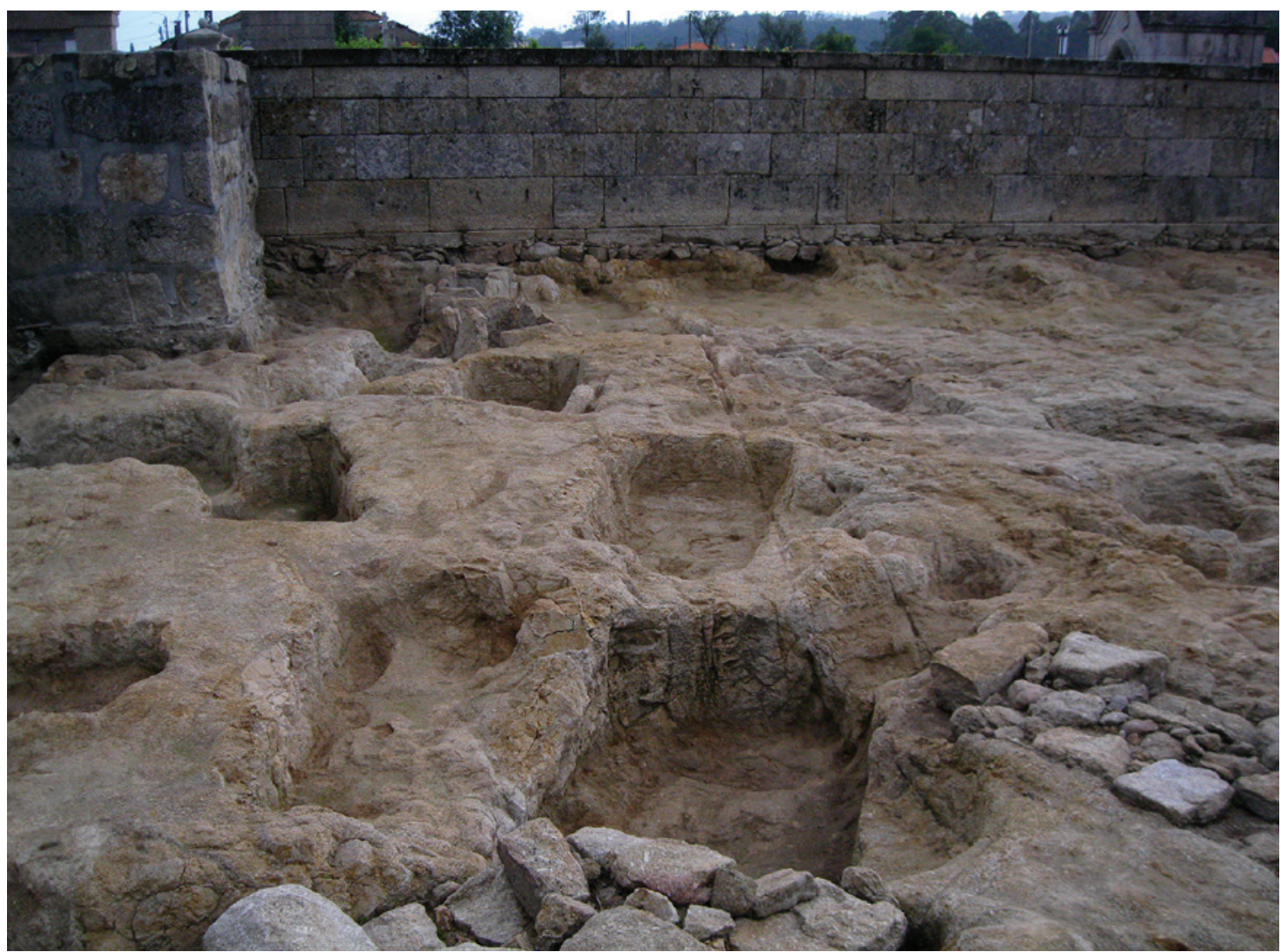

Figura 2 - Vista geral da intervenção na necrópole romana do Eirô (2016). 


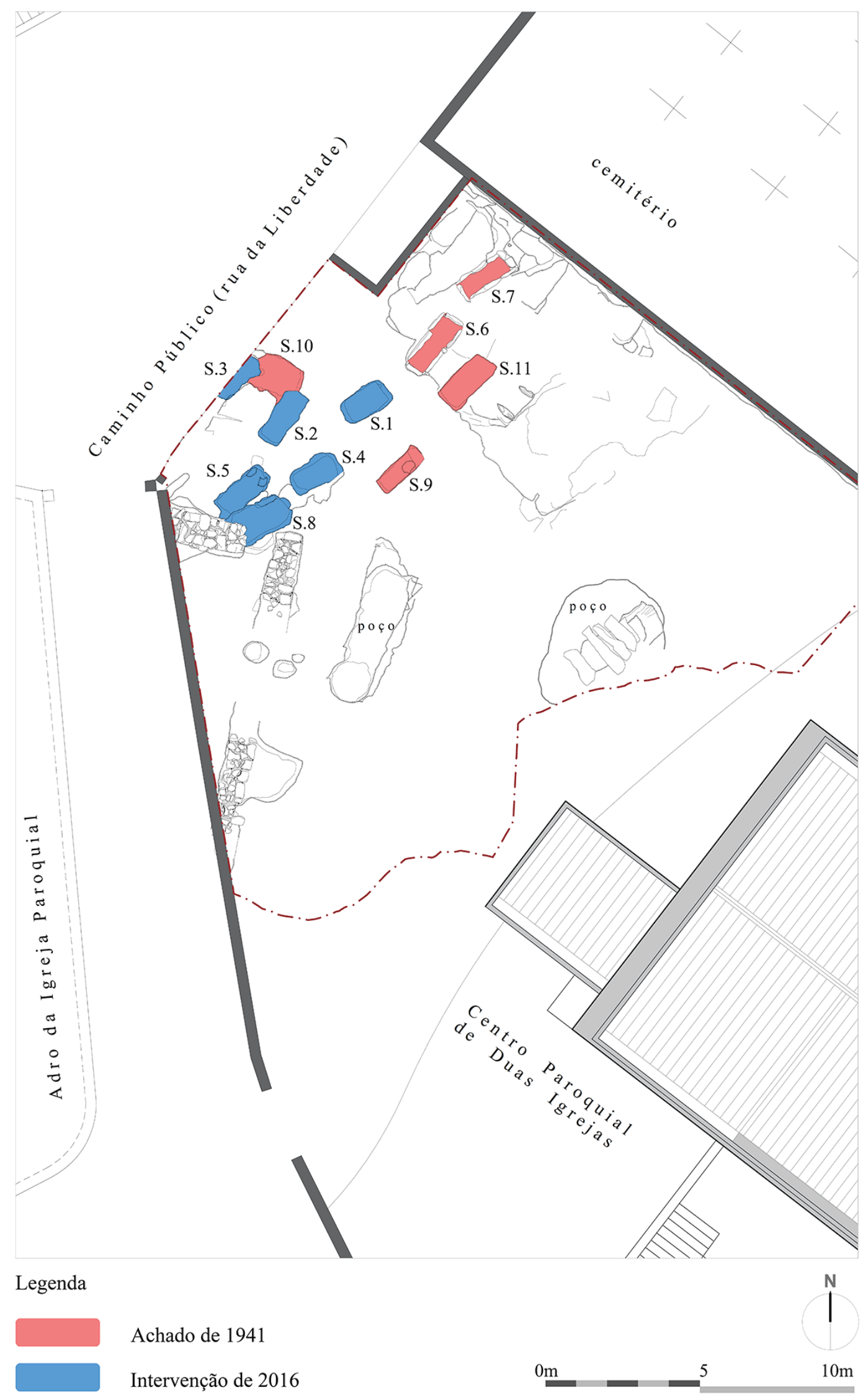

Figura 3 - Plano final da necrópole romana do Eirô (2016). 


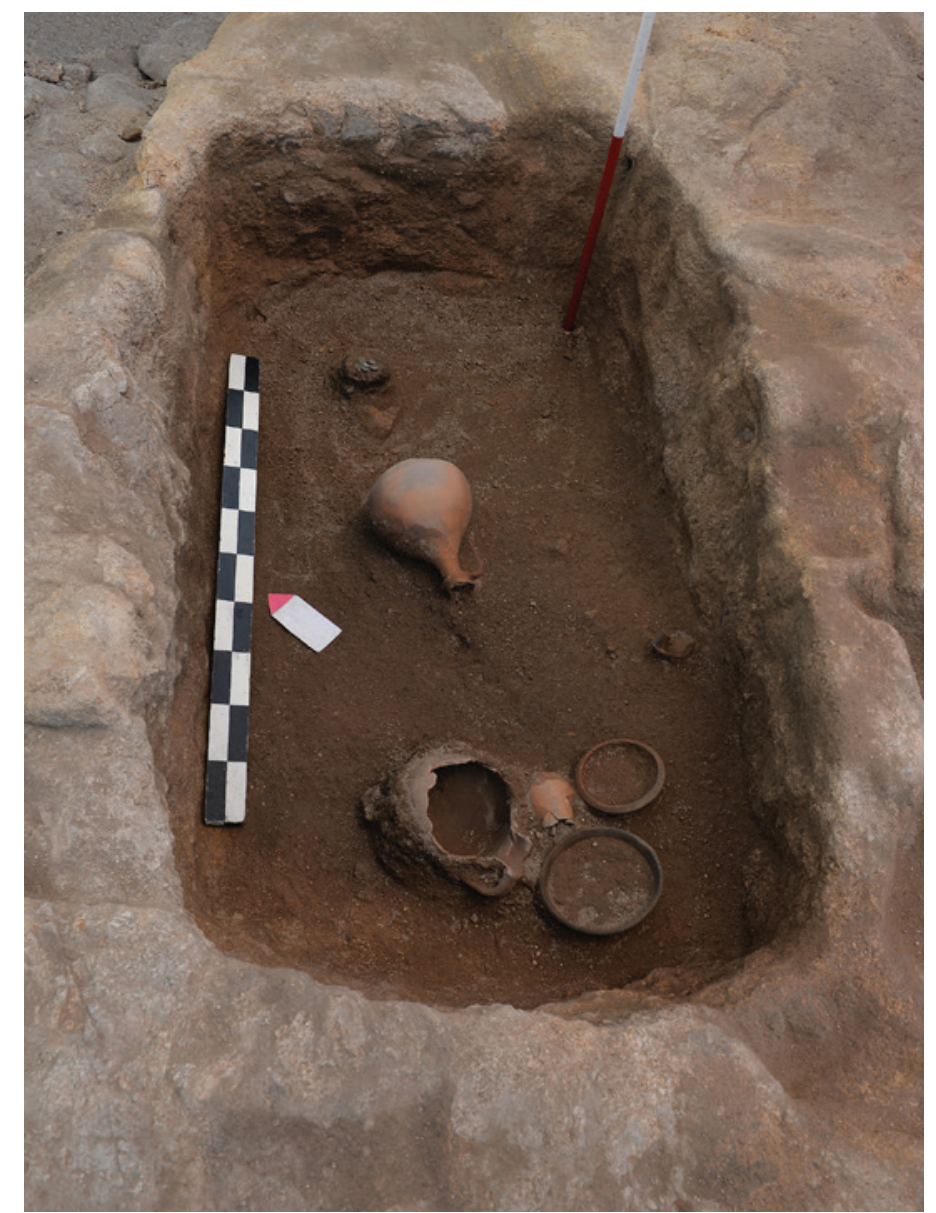

Figura 4 - Necrópole romana do Eirô: sepultura de inumação S. 1, com o respetivo mobiliário funerário.

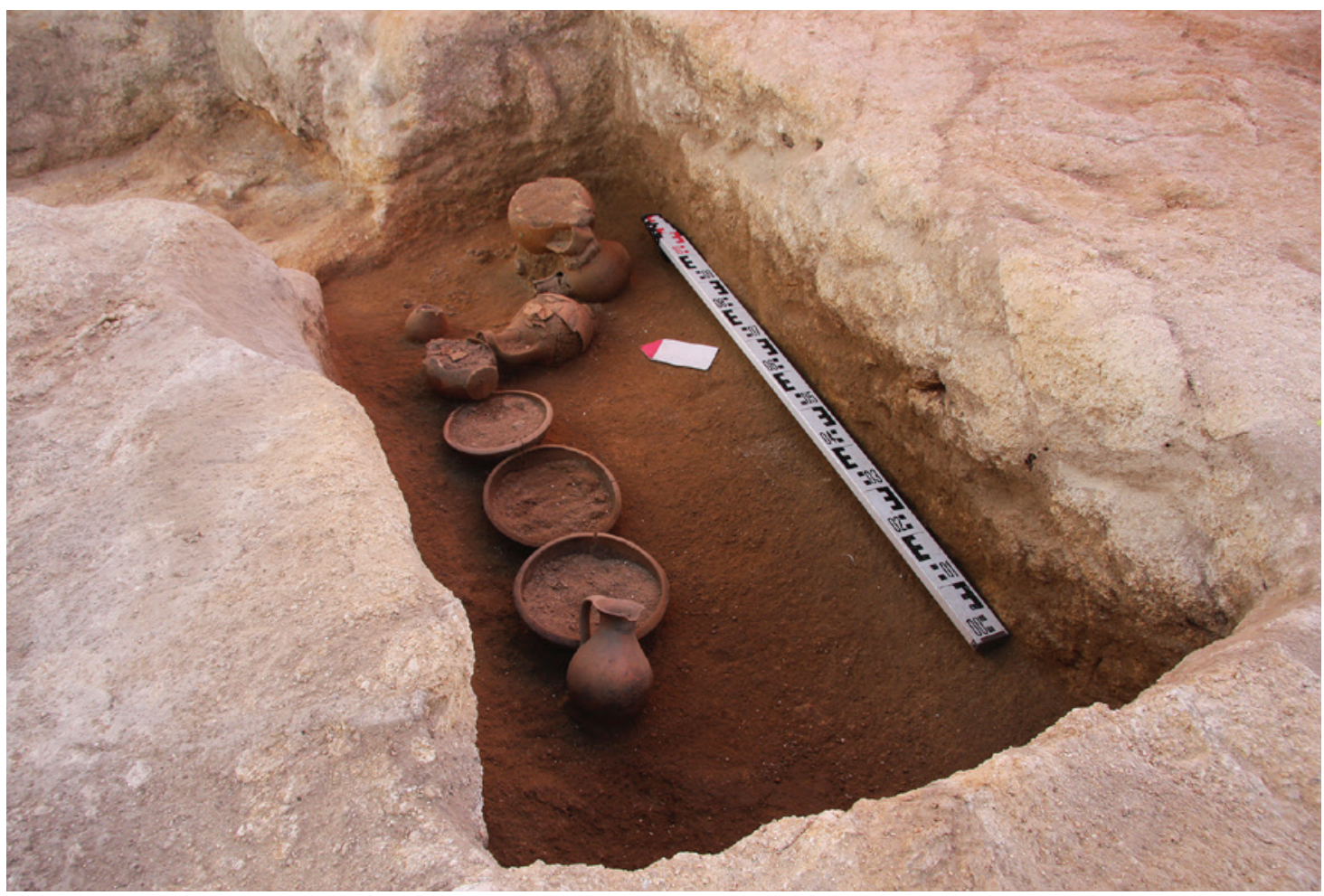

Figura 5-Necrópole romana do Eirô: sepultura de inumação S. 2, com o respetivo mobiliário funerário. 


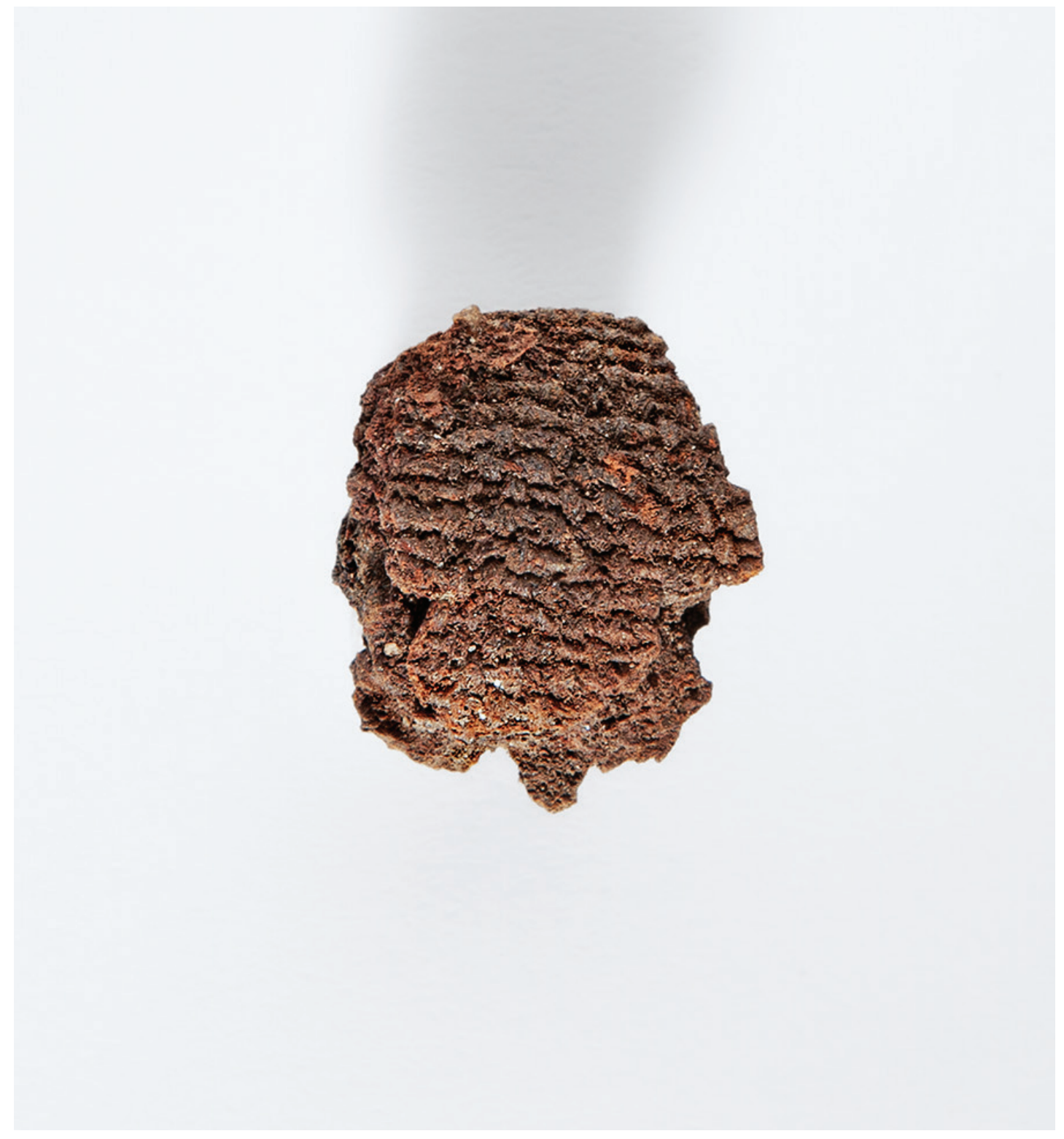

Figura 6 - Pormenor de tacha de calçado com vestígios de tecido, da S. 5 (fot. Eduardo Cunha). 


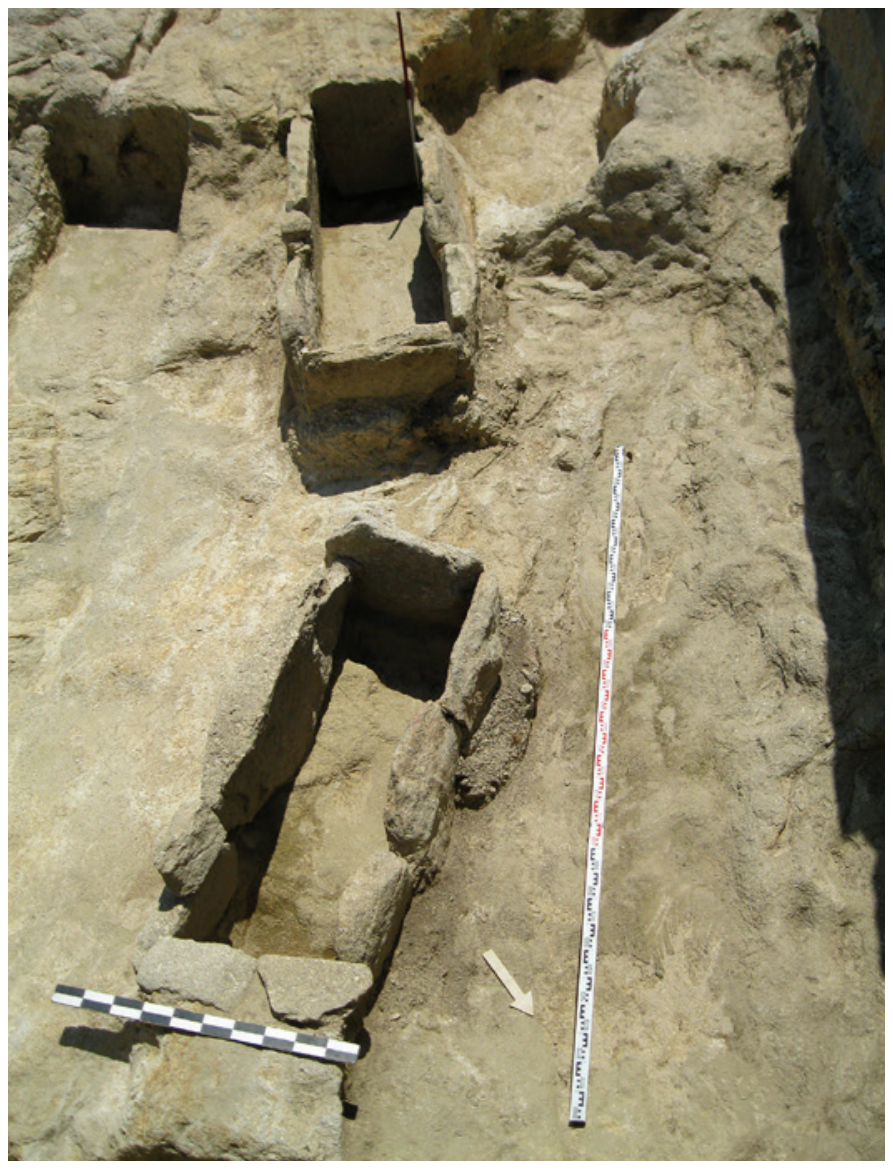

Figura 7-Sepulturas estruturadas com lajes, descobertas em 1941 (S. 6 e S. 7).

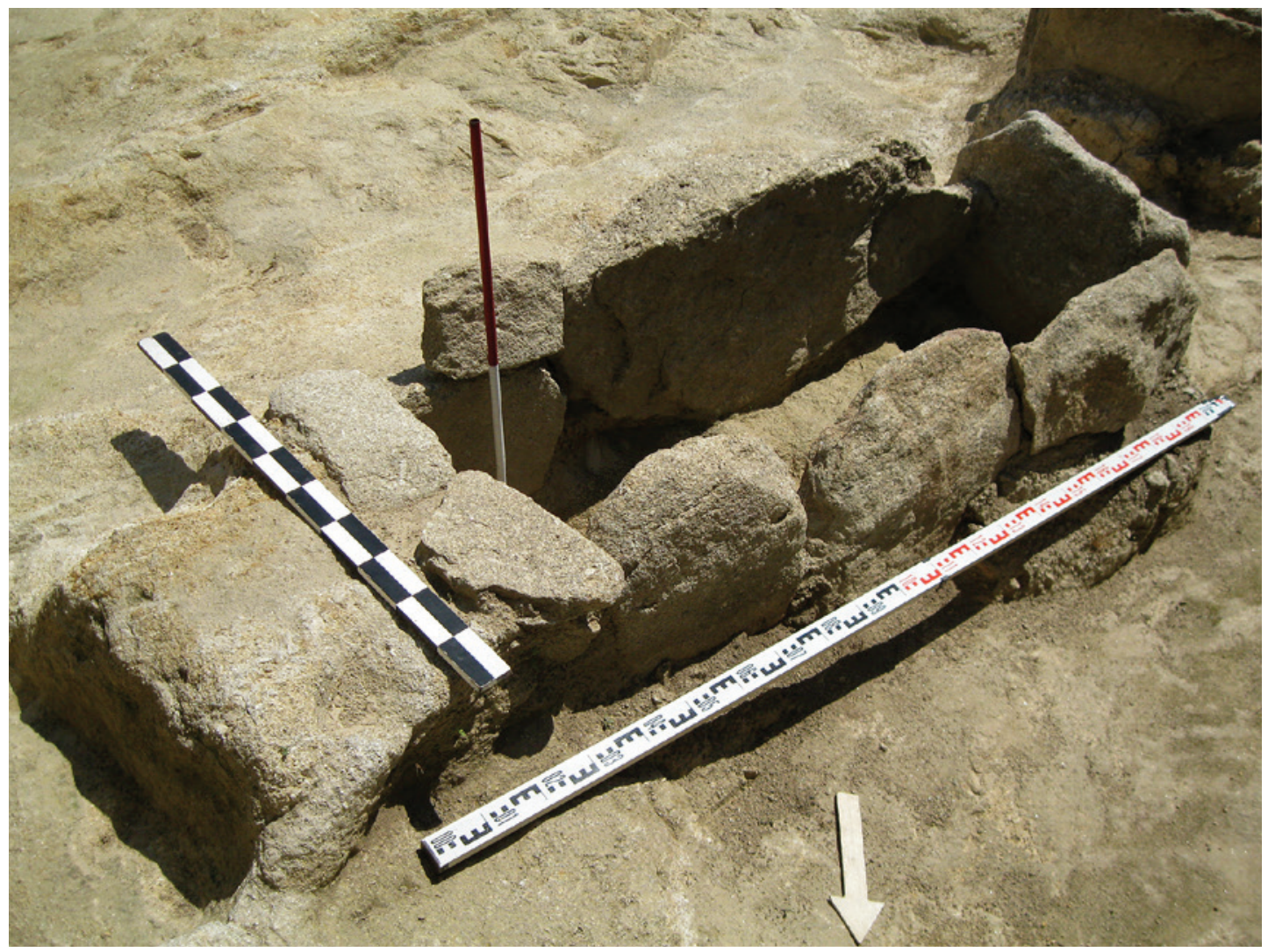

Figura 8 - Sepultura S. 7, evidenciando o sistema construtivo. 

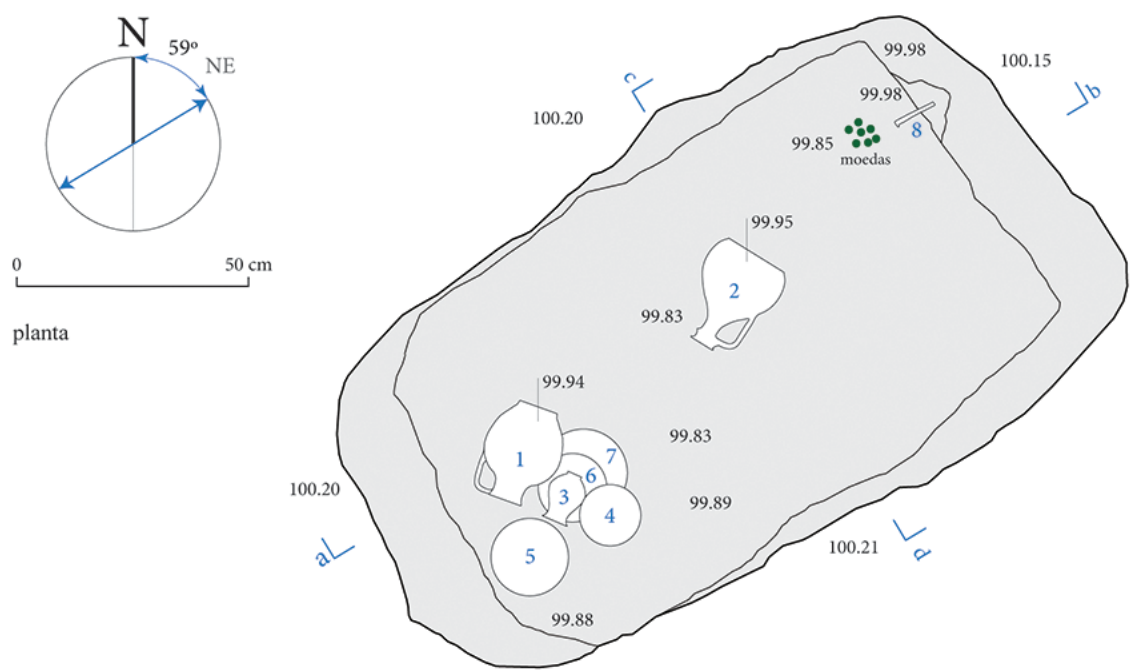

Sepultura 1

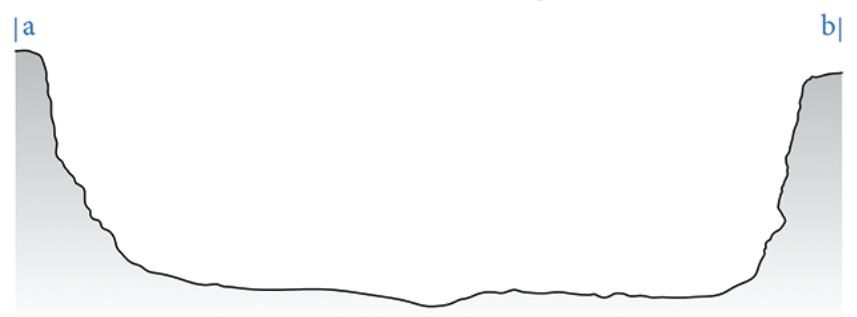

perfil longitudinal

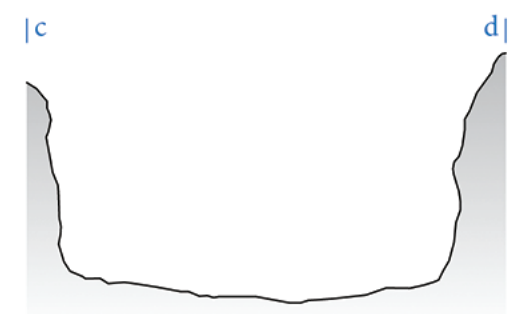

perfil transversal
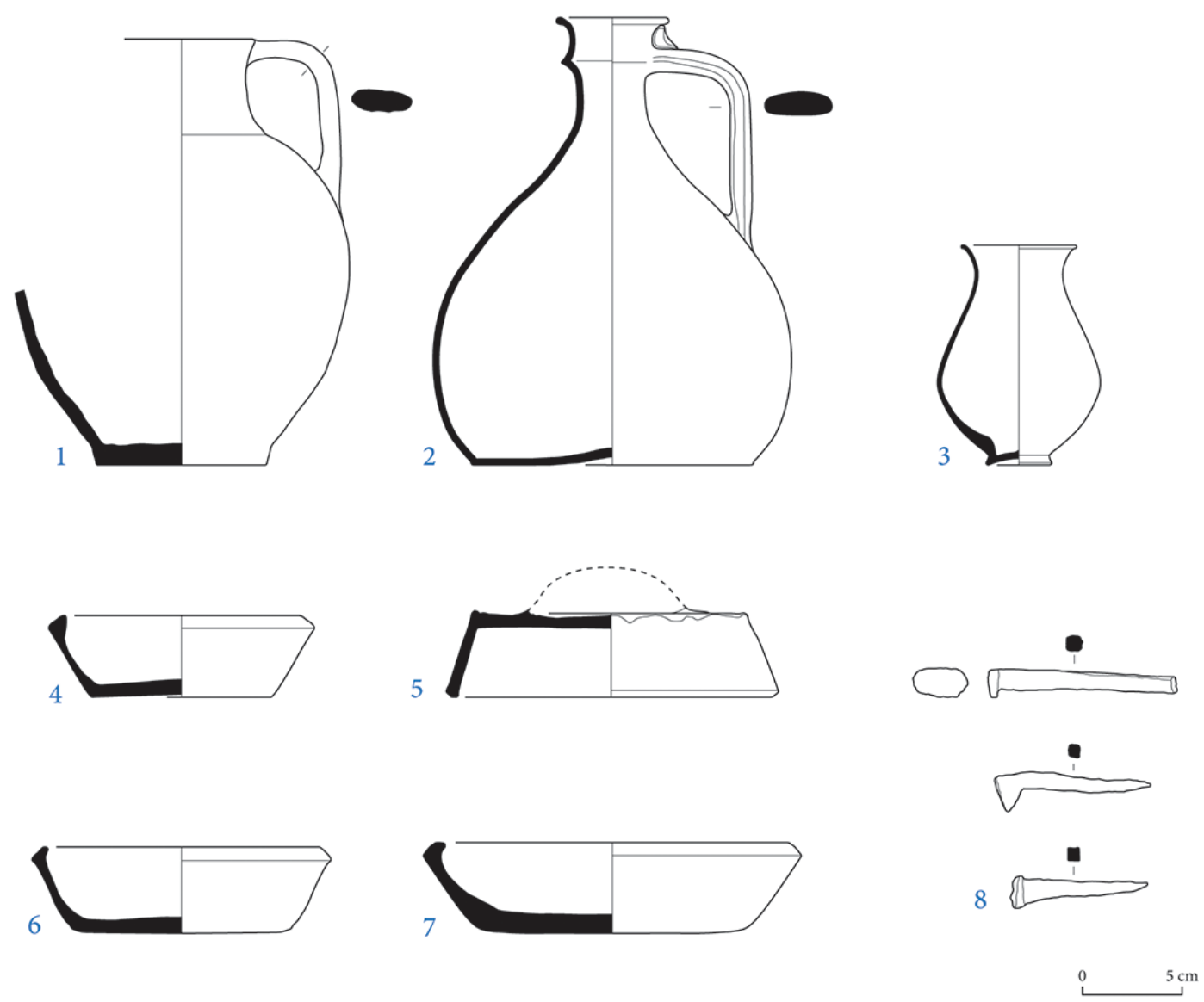

Figura 9 - Sepultura 1: plano, cortes e respetivo espólio. 

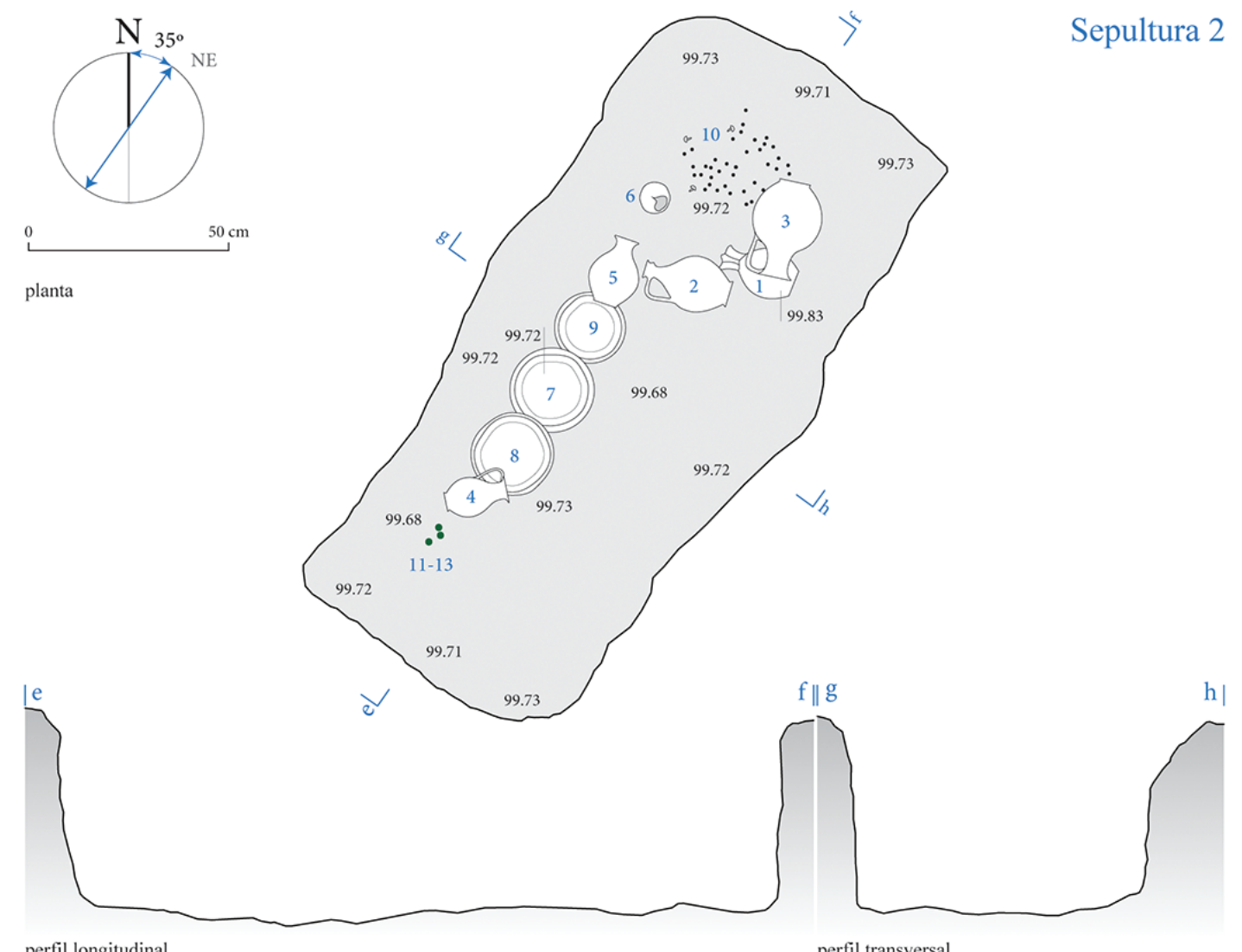

perfil transversal
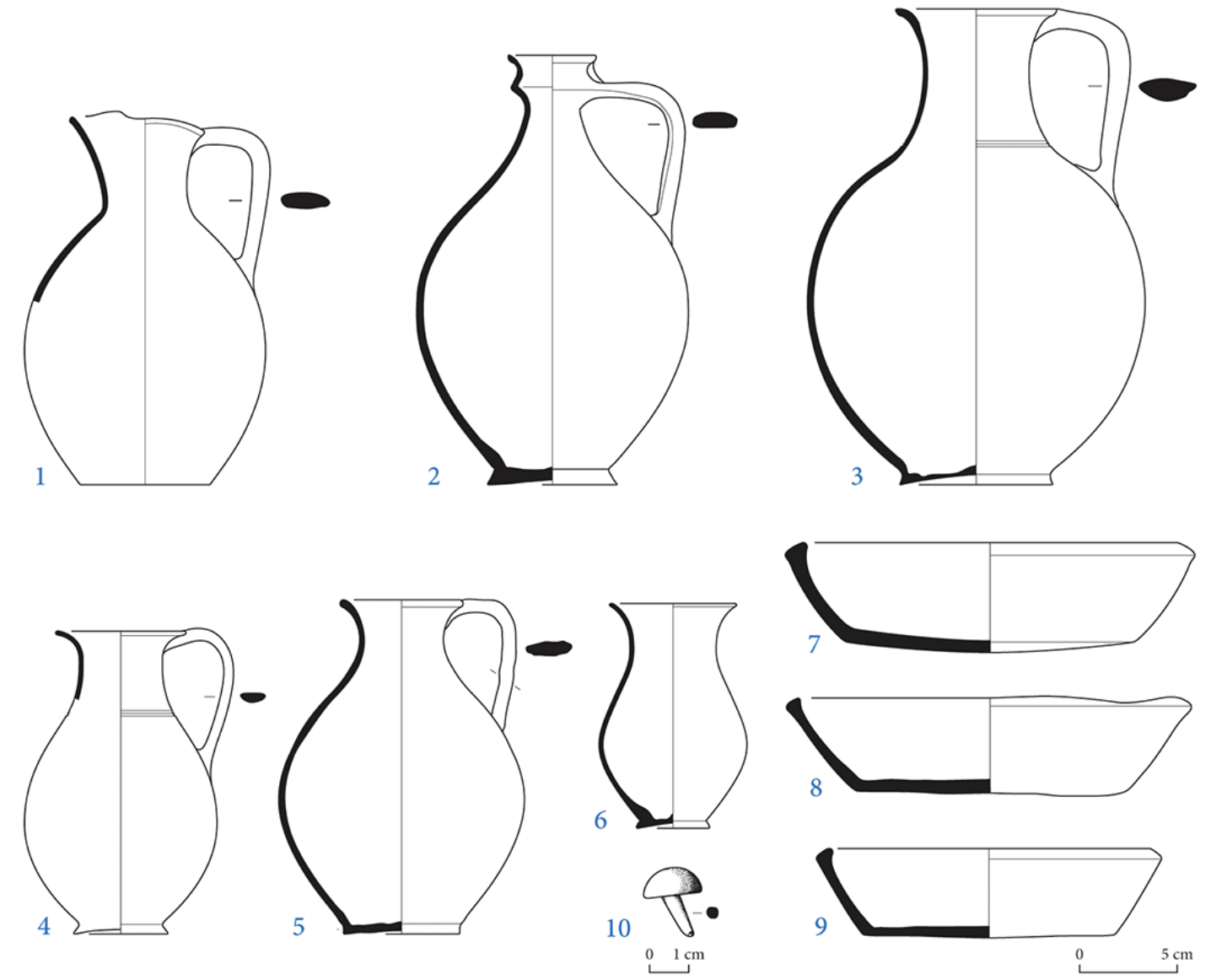

Figura 10 - Sepultura 2: plano, cortes e respetivo espólio. 

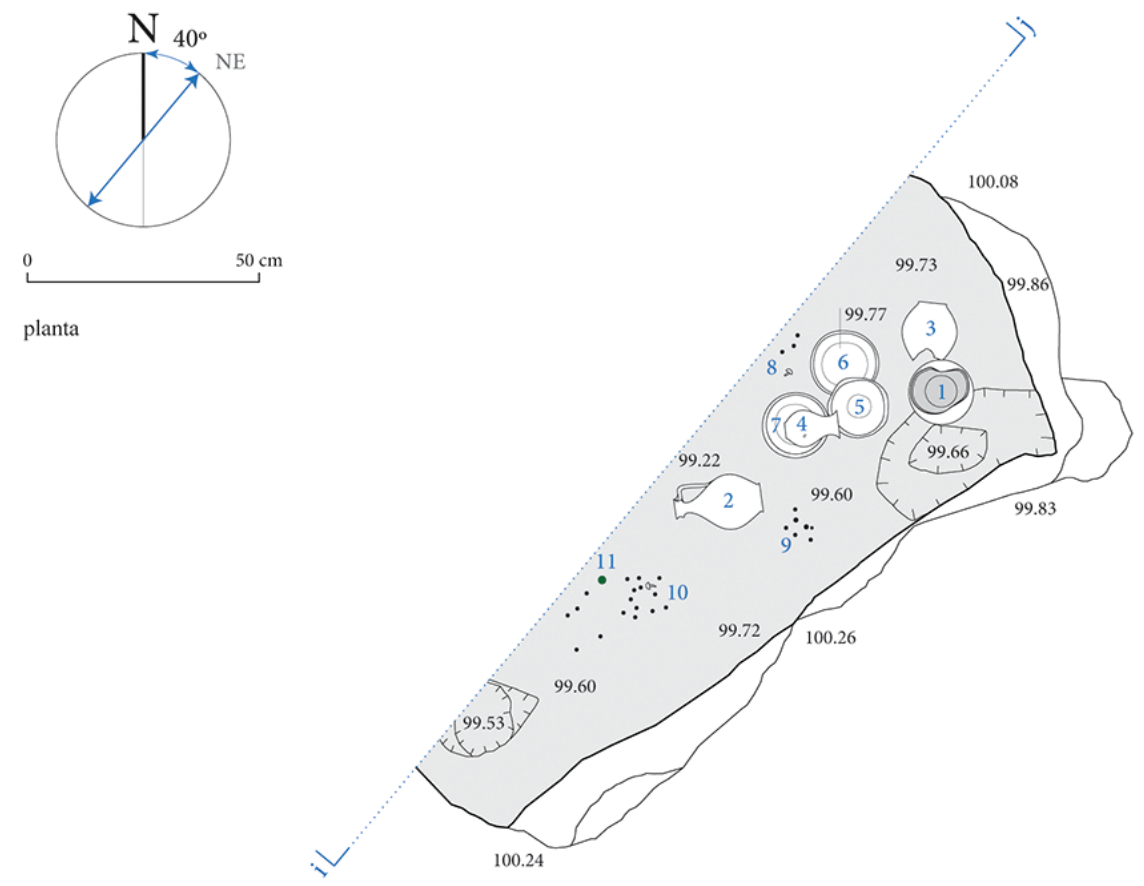

Sepultura 3

planta
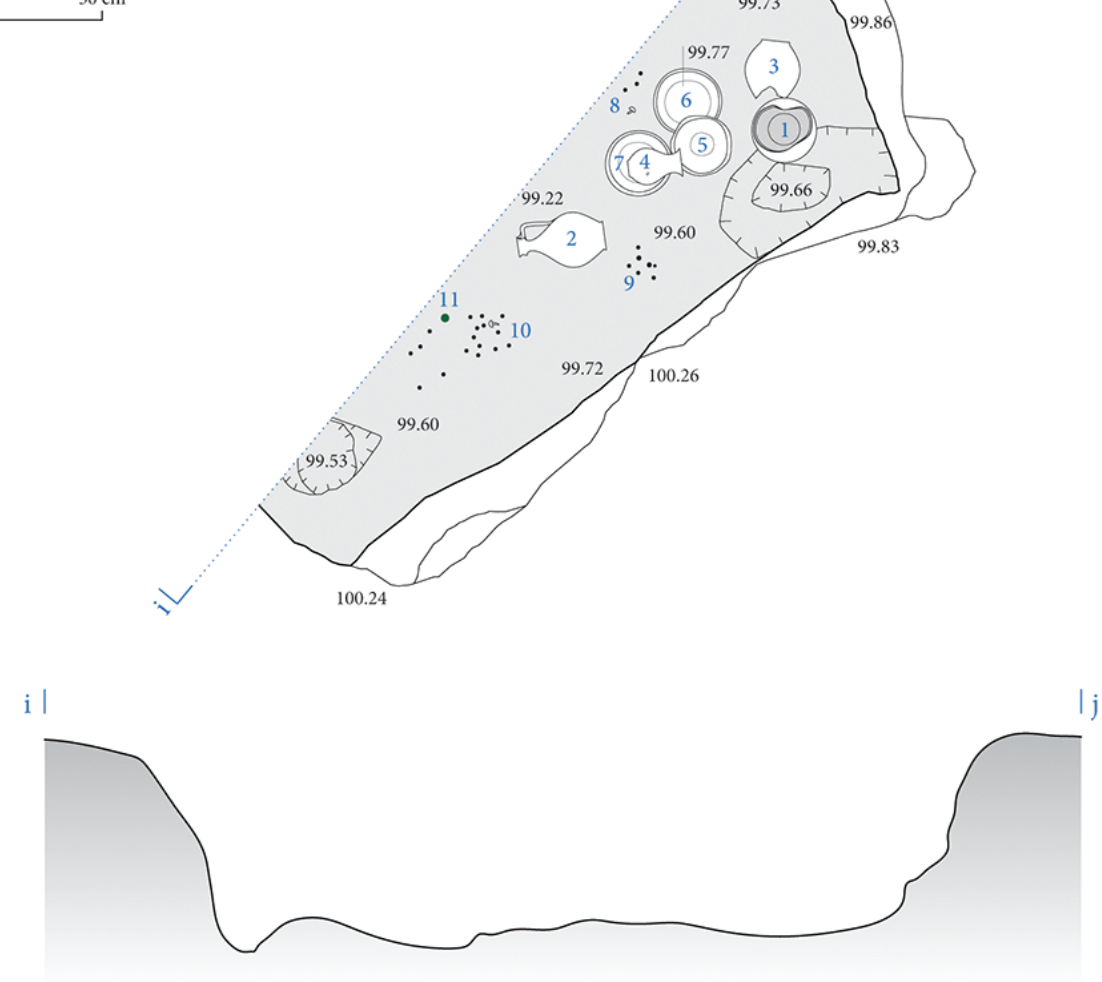

perfil longitudinal
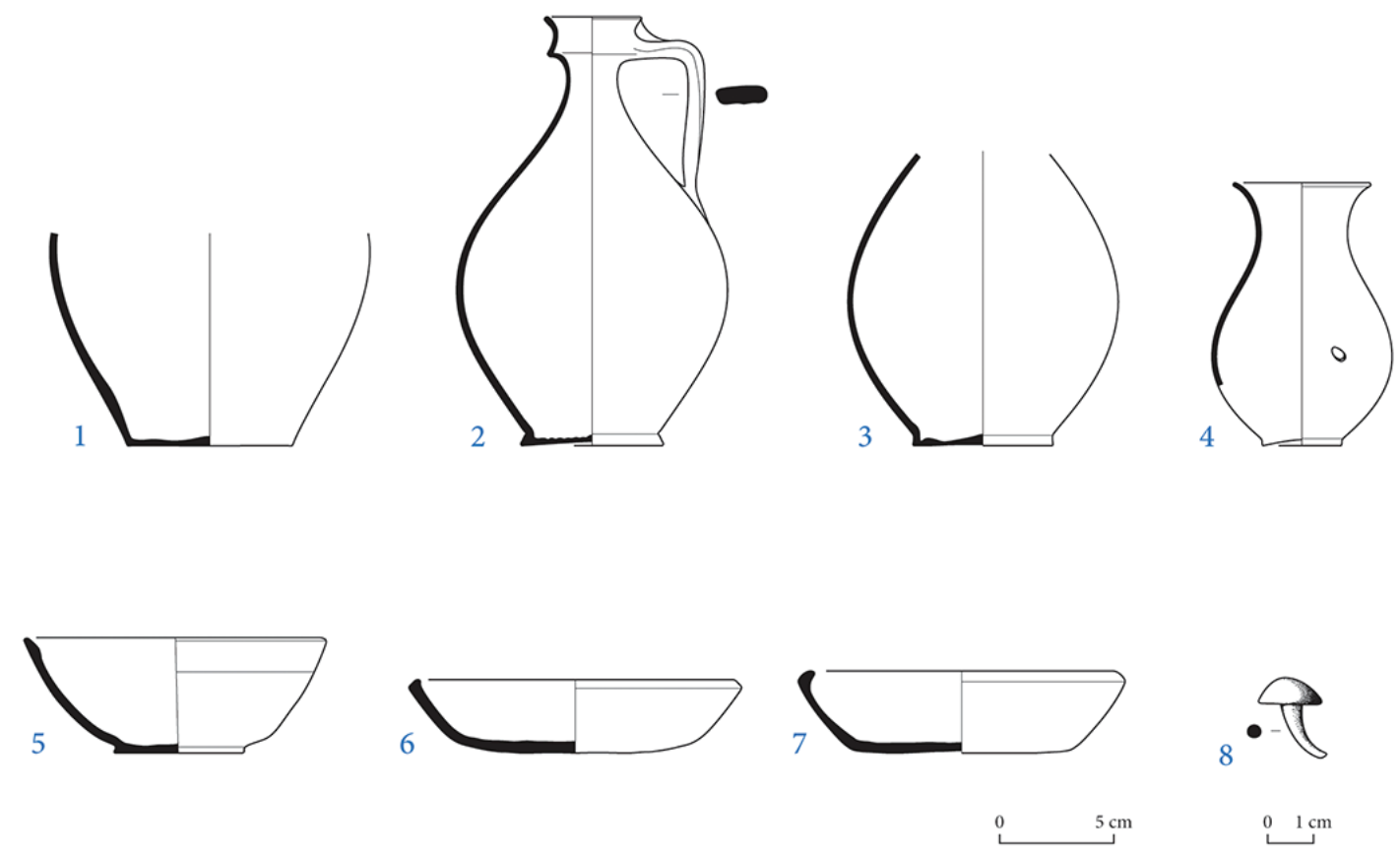

Figura 11 - Sepultura 3: plano, cortes e respetivo espólio. 


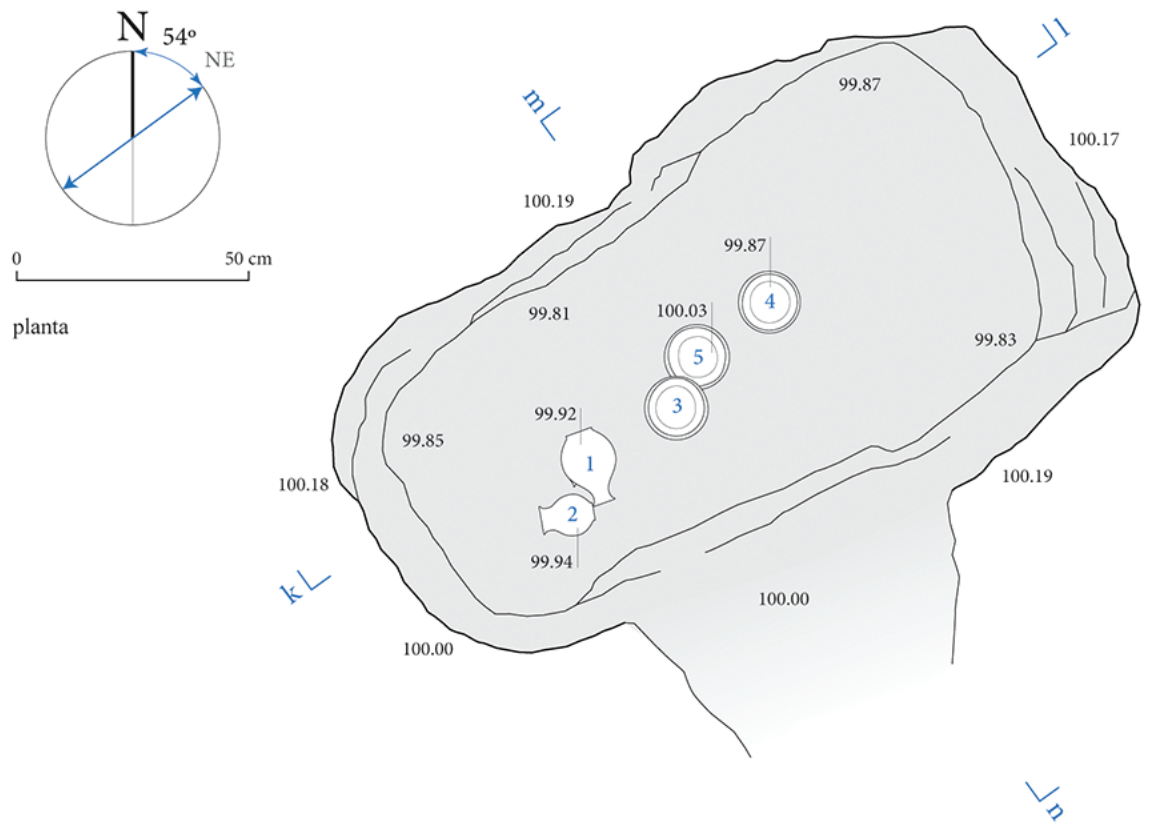

Sepultura 4

$\mathrm{k} \mid$

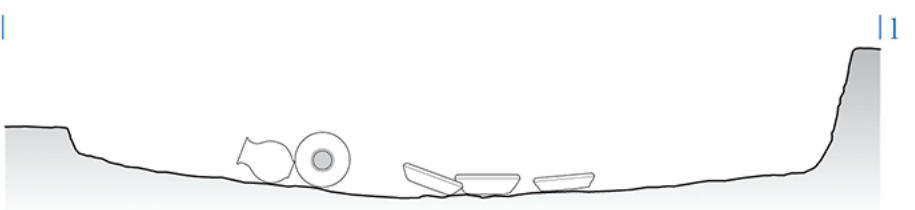

perfil longitudinal
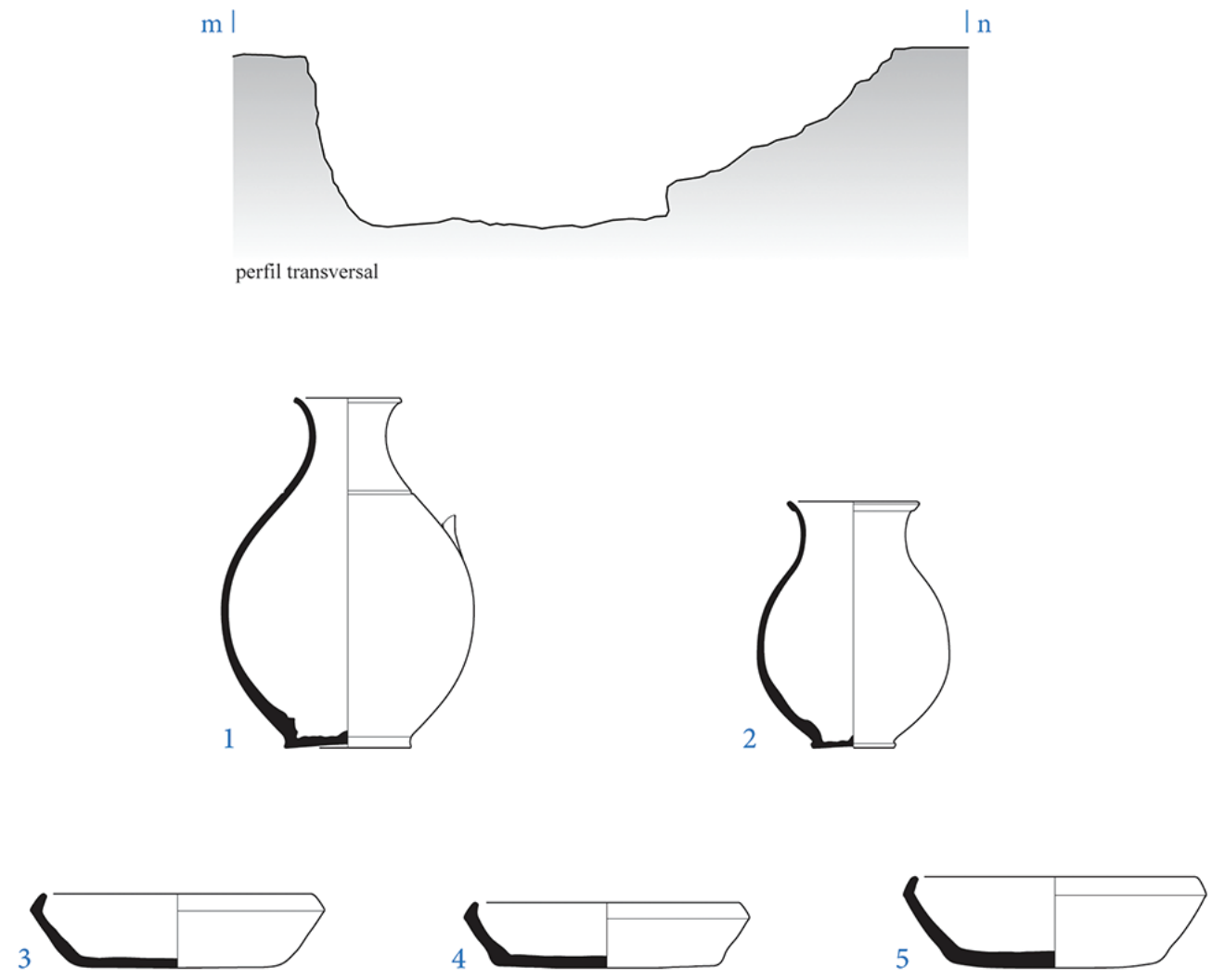

$\stackrel{0}{2}$

Figura 12 - Sepultura 4: plano, cortes e respetivo espólio. 


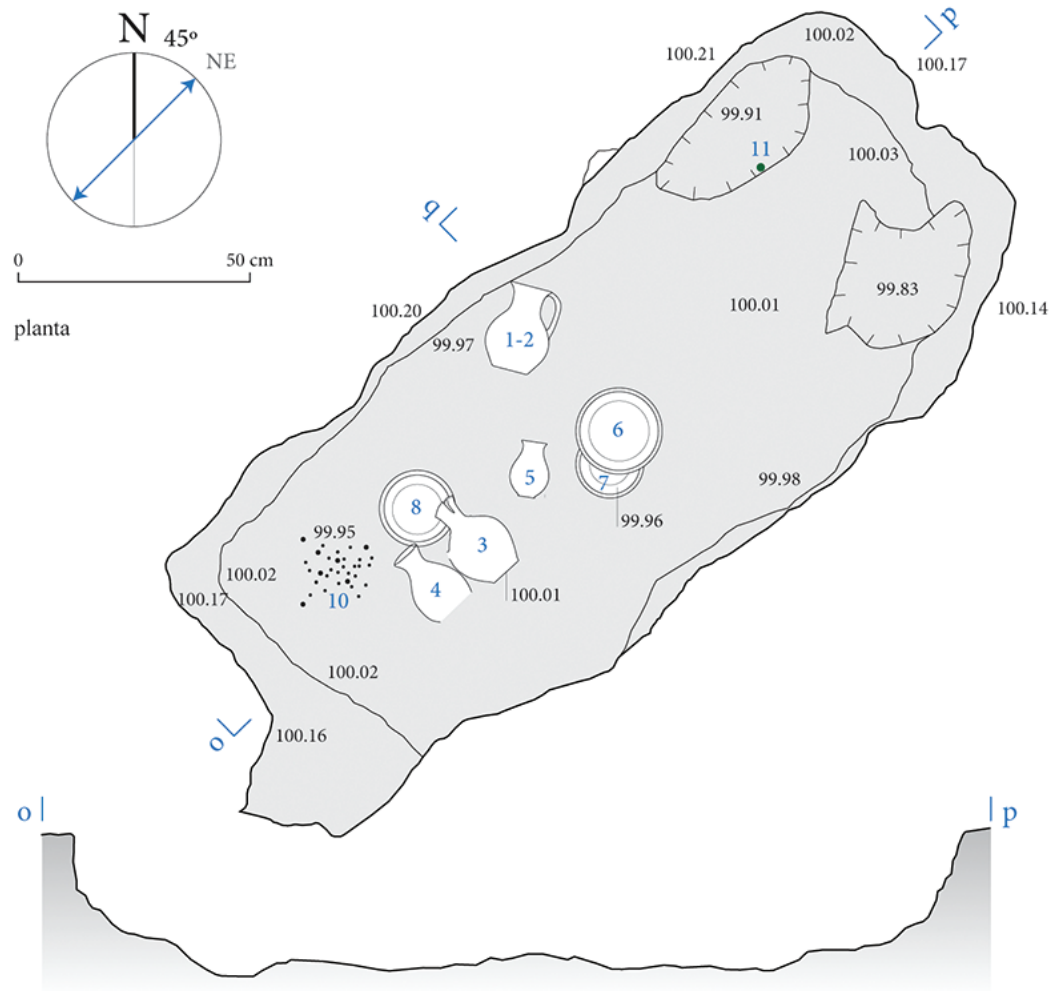

Sepultura 5

perfil longitudinal

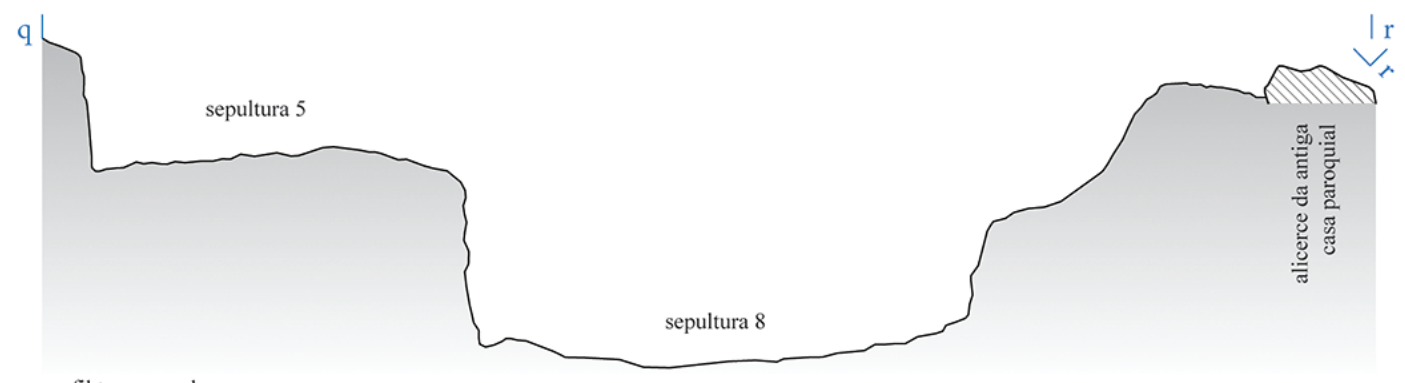

perfil transversal

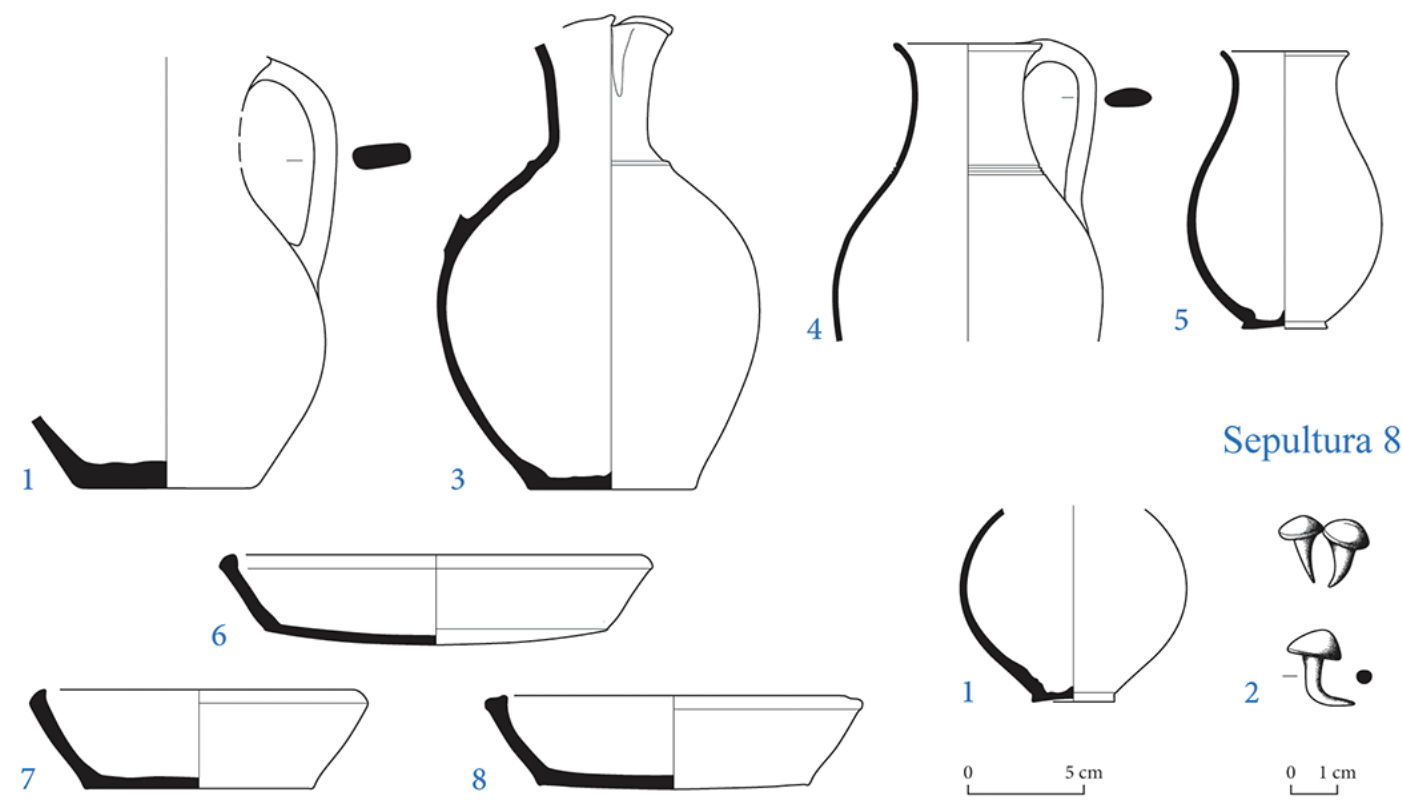

Figura 13 - Sepulturas 5 e 8: plano, cortes e respetivos espólios. 


\begin{tabular}{|c|c|}
\hline \multicolumn{2}{|r|}{ S. 1} \\
\hline Inv. & Objeto \\
\hline 14375 & $\begin{array}{l}\text { 1. Jarro - trilobado (?), p. arenosa, sup. alisada, } \\
\text { castanha; aparência nova }\end{array}$ \\
\hline 14376 & $\begin{array}{l}\text { 2. Bilha }- \text { p. arenosa, sup. } \pm \text { alisada, alaranjada, } \\
\text { bem cozida }\end{array}$ \\
\hline 14377 & $\begin{array}{l}\text { 3. Copo - p. arenosa fina, sup. alisada, bege, bem } \\
\text { cozida }\end{array}$ \\
\hline 14378 & $\begin{array}{l}\text { 4. Prato }- \text { p. arenosa, sup. } \pm \text { alisada, bege- } \\
\text { acastanhada }\end{array}$ \\
\hline 14379 & $\begin{array}{l}\text { 5. Tampa/Prato - perfil irregular, p. arenosa, sup. } \\
\text { pouco alisada, acastanhada, alguma fuligem no } \\
\text { int.; asa partida }\end{array}$ \\
\hline 14380 & $\begin{array}{l}\text { 6. Prato }- \text { p. arenosa, sup. } \pm \text { alisada, acastanhada, } \\
\text { fuligem no int. e ext. }\end{array}$ \\
\hline 14381 & $\begin{array}{l}\text { 7. Prato }- \text { p. arenosa, sup. } \pm \text { alisada, castanha- } \\
\text { alaranjada, fuligem no int. e ext. }\end{array}$ \\
\hline 14382 & 8. Objetos em ferro - pregos e ferragens \\
\hline 14383 & $\begin{array}{l}\text { 9. Nummus, Divus Constantinus I, C. M. ilegível, } \\
337-40 \\
\text { Rev.) Constantino em quadriga à direita }\end{array}$ \\
\hline 14384 & $\begin{array}{l}\text { 10. Nummus, Constantinus I, Constantinus II, } \\
\text { Constatius II ou Constans, C. M. ilegível, 335-40 } \\
\text { Rev.) Gloria Exercitus (1 estandarte) }\end{array}$ \\
\hline 14385 & $\begin{array}{l}\text { 11. } \text { \& 3, Constantius II, C. M. ilegível, 357-361 } \\
\text { Rev.) Spes Reipublice }\end{array}$ \\
\hline 14386 & $\begin{array}{l}\text { 12. Æ 3, Constantius II, C. M. ilegível, 355-357 } \\
\text { Rev.) Fel Temp. Reparatio (FH3) }\end{array}$ \\
\hline 14387 & $\begin{array}{l}\text { 13. Nummus, Constantius II, Antioquia, } 347-348 \text {, } \\
\text { RIC VIII, } 113 \text {. } \\
\text { Rev.) VOT/XX/MVLT/XXX dentro de coroa de } \\
\text { louros }\end{array}$ \\
\hline 14388 & $\begin{array}{l}\text { 14. Æ 3, Constantius II, C. M. ilegível, 355-357 } \\
\text { Rev.) Fel Temp. Reparatio (FH3) }\end{array}$ \\
\hline 14389 & $\begin{array}{l}\text { 15. Æ 3, Constantius II, C. M. ilegível, 355-357 } \\
\text { Rev.) Fel Temp. Reparatio (FH3) }\end{array}$ \\
\hline 14390 & $\begin{array}{l}\text { 16. Nummus, Constantius II, C. M. Ocidental, } \\
347-348 \\
\text { Rev.) Victoriae DD Augg Q NN }\end{array}$ \\
\hline \multicolumn{2}{|r|}{ S. 2} \\
\hline Inv. & Objeto \\
\hline 14394 & $\begin{array}{l}1 \text { Jarro - trilobado, bico unido, p. arenosa, sup. } \pm \\
\text { alisada, castanha, fuligem exceto na zona da asa }\end{array}$ \\
\hline 14395 & $\begin{array}{l}\text { 2. Bilha }- \text { p. arenosa fina, sup. } \pm \text { alisada, bege- } \\
\text { alaranjada, bem cozida }\end{array}$ \\
\hline 14396 & $\begin{array}{l}\text { 3. Púcaro - grande, p. arenosa com grãos } \\
\text { vermelhos, sup. alisada, bege com manchas de } \\
\text { tom alaranjado }\end{array}$ \\
\hline 14397 & $\begin{array}{l}\text { 4. Púcaro - p. arenosa fina, sup. alisada, castanha } \\
\text { com manchas de tom alaranjado, fuligem do lado } \\
\text { oposto à asa }\end{array}$ \\
\hline 14398 & $\begin{array}{l}\text { 5. Púcaro - p. arenosa fina, sup. alisada, castanha- } \\
\text { alaranjada }\end{array}$ \\
\hline 14399 & 6. Copo - p. arenosa fina, sup. alisada, bege \\
\hline 14400 & $\begin{array}{l}\text { 7. Prato - perfil irregular, p. arenosa, sup. } \pm \\
\text { alisada, castanha, fuligem no int. e ext. }\end{array}$ \\
\hline 14401 & $\begin{array}{l}\text { 8. Prato de lume }- \text { p. arenosa, sup. } \pm \text { alisada, } \\
\text { castanha, fuligem no int. e ext. }\end{array}$ \\
\hline 14402 & $\begin{array}{l}\text { 9. Prato de lume }- \text { p. arenosa, sup. } \pm \text { alisada, } \\
\text { acastanhada, fuligem no ext. }\end{array}$ \\
\hline 14403 & $\begin{array}{l}\text { 10. Tachas - } 63 \text {, de tamanho pequeno e médio, } \\
\text { com sinais do tecido, pouco percetível }\end{array}$ \\
\hline 14404 & $\begin{array}{l}\text { 11. } \text { E 3, Constantius II, C. M. ilegível, 355-357 } \\
\text { Rev.) Fel Temp. Reparatio (FH3) }\end{array}$ \\
\hline 14405 & $\begin{array}{l}\text { 12. } Æ \text { 3, Constantius II, C. M. ilegível, 355-357 } \\
\text { Rev.) Fel Temp. Reparatio (FH3) }\end{array}$ \\
\hline 14406 & $\begin{array}{l}\text { 13. } Æ \text { 3, fragmentada, ilegível, séc. IV (post. } \\
330 \text { ?) }\end{array}$ \\
\hline
\end{tabular}

\begin{tabular}{|c|c|}
\hline \multicolumn{2}{|r|}{ S. 3} \\
\hline Inv. & Objeto \\
\hline 14407 & $\begin{array}{l}\text { 1. Jarro - p. arenosa, sup. } \pm \text { alisada, castanha, } \\
\text { fuligem exceto na zona da asa (?) }\end{array}$ \\
\hline 14408 & $\begin{array}{l}\text { 2. Bilha - p. fina com desengordurante cerâmico, } \\
\text { sup. bem alisada, bege-alaranjada }\end{array}$ \\
\hline 14409 & $\begin{array}{l}\text { 3. Púcaro (?) - p. arenosa fina, sup. alisada, bege- } \\
\text { alaranjada, fuligem no lado oposta à asa }\end{array}$ \\
\hline 14410 & $\begin{array}{l}\text { 4. Copo - p. arenosa fina, sup. alisada, bege- } \\
\text { alaranjada, orifício aberto na pança depois da } \\
\text { cozedura }\end{array}$ \\
\hline 14411 & $\begin{array}{l}\text { 5. Tacinha - pasta arenosa } \pm \text { fina, sup. bem } \\
\text { alisada, bege-alaranjada, forte aguada castanho- } \\
\text { alaranjado no int. e ext. do lábio }\end{array}$ \\
\hline 14412 & $\begin{array}{l}\text { 6. Pratel - pasta arenosa } \pm \text { fina, sup. bem alisada, } \\
\text { bege-alaranjada }\end{array}$ \\
\hline 14413 & $\begin{array}{l}\text { 7. Prato - p. arenosa, sup. alisada, castanha, } \\
\text { fuligem no int. e ext. }\end{array}$ \\
\hline 14414 & $\begin{array}{l}\text { 8. Tachas - } 4 \text { médias, com marcas ténues de } \\
\text { tecido }\end{array}$ \\
\hline 14415 & $\begin{array}{l}\text { 9. Tachas }-7 \text { pequenas e médias, com marcas } \\
\text { ténues de tecido }\end{array}$ \\
\hline 14416 & $\begin{array}{l}\text { 10. Tachas - } 18 \text { pequenas, algumas com marcas } \\
\text { de tecido }\end{array}$ \\
\hline 14417 & $\begin{array}{l}\text { 11. Nummus ou } Æ \mathbf{~} \mathbf{3} \mathbf{4} \text { (?), fragmentado, século } \\
\text { IV (post. 330?) }\end{array}$ \\
\hline \multicolumn{2}{|r|}{ S. 4} \\
\hline Inv. & Objeto \\
\hline 14418 & 1. Púcaro - p. arenosa fina, sup. alisada, bege \\
\hline 14419 & 2. Copo - p. arenosa fina, sup. alisada, bege \\
\hline 14420 & $\begin{array}{l}\text { 3. Prato - p. arenosa, sup. } \pm \text { alisada, bege- } \\
\text { acastanhada }\end{array}$ \\
\hline 14421 & $\begin{array}{l}\text { 4. Prato }- \text { p. arenosa, sup. } \pm \text { alisada, bege- } \\
\text { acastanhada }\end{array}$ \\
\hline 14422 & $\begin{array}{l}\text { 5. Prato - perfil irregular, p. com grãos de } \\
\text { quartzo, ext. alisado, acastanhado, fuligem no int. } \\
\text { e ext. }\end{array}$ \\
\hline 14423 & $\begin{array}{l}\text { 6. Objeto de bronze - fragmento reto de secção } \\
\text { circular, com revestimento de natureza orgânica }\end{array}$ \\
\hline \multicolumn{2}{|r|}{ S. 5} \\
\hline Inv. & Objeto \\
\hline 14470 & $\begin{array}{l}\text { 1. Jarro - trilobado(?), p. arenosa, sup. alisada, } \\
\text { castanha-alaranjada, bem cozida, com fuligem }\end{array}$ \\
\hline 14471 & $\begin{array}{l}\text { 2. Tachas }-8 \text {, idênticas às outras, mas sem (?) } \\
\text { marcas de tecido }\end{array}$ \\
\hline 14472 & $\begin{array}{l}\text { 3. Jarro - trilobado, p. arenosa, sup. alisada, } \\
\text { castanha, fuligem no ext. }\end{array}$ \\
\hline 14473 & $\begin{array}{l}\text { 4. Púcaro - p. arenosa fina, sup. alisada, castanha- } \\
\text { avermelhada, bem cozida }\end{array}$ \\
\hline 14474 & $\begin{array}{l}\text { 5. Copo }- \text { p. arenosa } \pm \text { fina, sup. alisada, } \\
\text { acastanhada }\end{array}$ \\
\hline 14475 & $\begin{array}{l}\text { 6. Prato }- \text { p. arenosa, sup. } \pm \text { alisada, castanha- } \\
\text { alaranjada }\end{array}$ \\
\hline 14476 & $\begin{array}{l}\text { 7. Prato }- \text { p. arenosa, sup. } \pm \text { alisada, acastanhada, } \\
\text { fuligem no int. e ext. }\end{array}$ \\
\hline 14477 & 8. Prato - p. arenosa, sup. áspera, castanha \\
\hline 14478 & $\begin{array}{l}\text { 9. Vaso de vidro - fragmento mínimo de vidro } \\
\text { incolor, curvo, espessura }>1 \mathrm{~mm}\end{array}$ \\
\hline 14479 & $\begin{array}{l}\text { 10. Tachas }-83, \text { muitas com marcas de tecido } \\
\text { bem visíveis }\end{array}$ \\
\hline 14480 & $\begin{array}{l}\text { 11. Æ 3, Constantius II, Roma, 355-357, RIC VIII } \\
\text { 316. Rev.) Fel Temp. Reparatio (FH3) R. M. [?] }\end{array}$ \\
\hline \multicolumn{2}{|r|}{ S. 8} \\
\hline Inv. & Objeto \\
\hline 14481 & $\begin{array}{l}\text { 1. Púcaro (?) - p. arenosa fina, sup. alisada, bege, } \\
\text { bem cozida }\end{array}$ \\
\hline 14482 & $\begin{array}{l}\text { 2. Tachas }-32 \text {, de tamanho pequeno e médio, } \\
\text { com sinais do tecido }\end{array}$ \\
\hline
\end{tabular}

Tabela 1 - Necrópole Romana do Eirô (Duas Igrejas, Penafiel, 2016): síntese dos artefactos pertencentes a cada enterramento. 


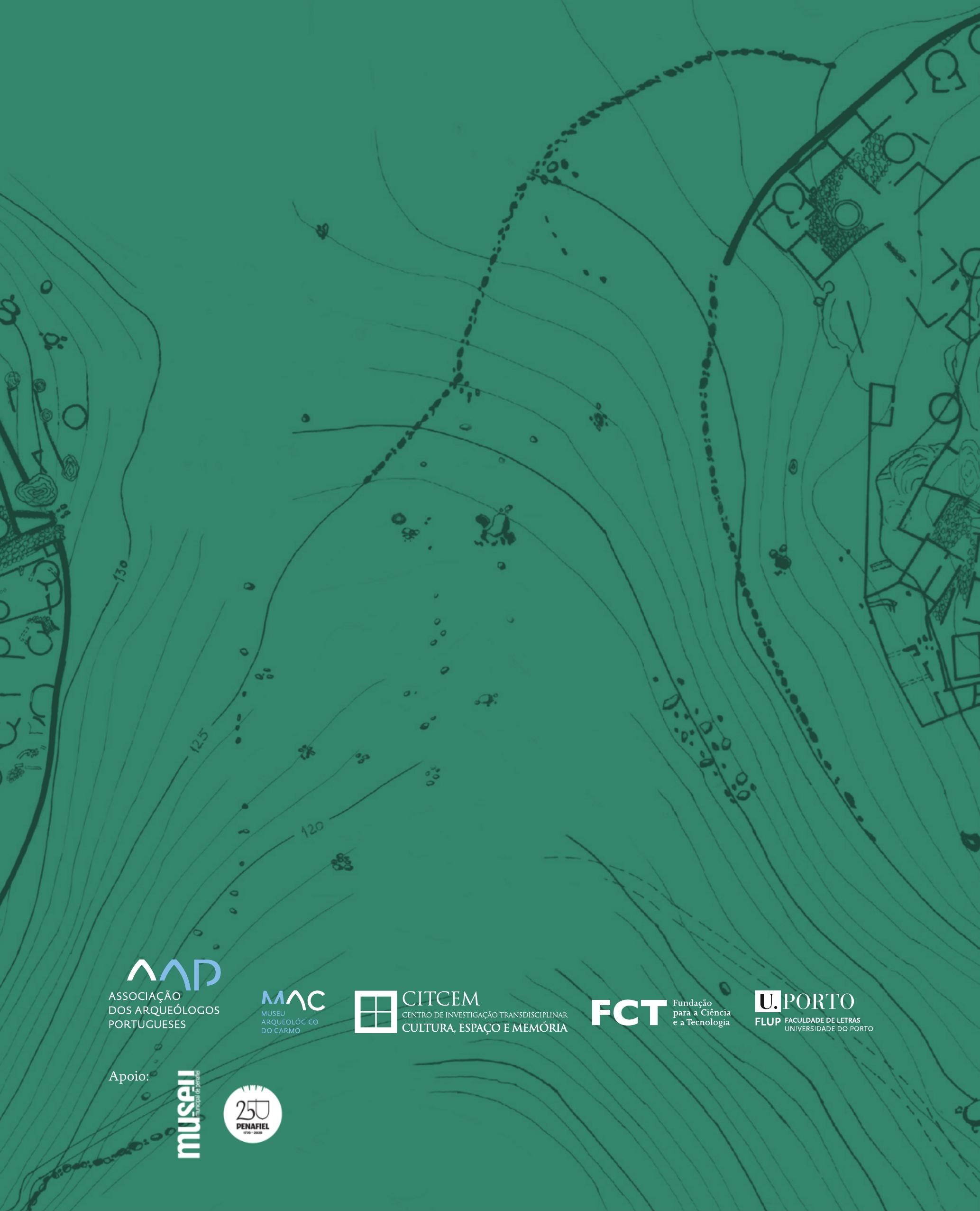

